\title{
Biological Properties, Bioactive Constituents, and Pharmacokinetics of Some Capsicum spp. and Capsaicinoids
}

\author{
Gaber El-Saber Batiha ${ }^{1, *,+}{ }^{\infty}$, Ali Alqahtani ${ }^{2}{ }^{\circ}$, Oluwafemi Adeleke Ojo ${ }^{3}{ }^{(0,}$ \\ Hazem M. Shaheen ${ }^{1}$ (D), Lamiaa Wasef ${ }^{1}$, Mahmoud Elzeiny ${ }^{1}$, Mahmoud Ismail ${ }^{1}$, \\ Mahmoud Shalaby ${ }^{1}$, Toshihiro Murata ${ }^{4}$, Adrian Zaragoza-Bastida ${ }^{5} \mathbb{D}$, Nallely Rivero-Perez ${ }^{5}$ (D), \\ Amany Magdy Beshbishy ${ }^{6, *, \dagger}$, Keneth Iceland Kasozi ${ }^{7}\left(\mathbb{D}\right.$, Philippe Jeandet ${ }^{8}$ and \\ Helal F. Hetta $9,10, *$ (D)
}

1 Department of Pharmacology and Therapeutics, Faculty of Veterinary Medicine, Damanhour University, Damanhour 22511, AlBeheira, Egypt; dr_hazemshaheen3010@yahoo.com (H.M.S.); lamiaawasef@vetmed.dmu.edu.eg (L.W.); mahmoudelzeiny755@gmail.com (M.E.); mahmoudesmail7899@gmail.com (M.I.); eidm98282@gmail.com (M.S.)

2 Department of Pharmacology, College of Pharmacy, King Khalid University, Guraiger, Abha 62529, Saudi Arabia; amsfr@kku.edu.sa

3 Department of Biochemistry, Landmark University, Omu-Aran 251101, Nigeria; ojo.adeleke@lmu.edu.ng

4 Department of Pharmacognosy, Tohoku Medical and Pharmaceutical University, Aoba-ku, Sendai 981-8558, Japan; murata-t@tohoku-mpu.ac.jp

5 Área Académica de Medicina Veterinaria y Zootecnia, Instituto de Ciencias Agropecuarias, Universidad Autónoma del Estado de Hidalgo, Rancho Universitario Av. Universidad km 1, EX-Hda de Aquetzalpa, Tulancingo, Hidalgo 43600, Mexico; adrian_zaragoza@uaeh.edu.mx (A.Z.-B.); nallely_rivero@uaeh.edu.mx (N.R.-P.)

6 National Research Center for Protozoan Diseases, Obihiro University of Agriculture and Veterinary Medicine, Nishi 2-13, Inada-cho, Obihiro 080-8555, Hokkaido, Japan

7 Infection Medicine, Deanery of Biomedical Sciences, College of Medicine and Veterinary Medicine, The University of Edinburgh, 1 George Square, Edinburgh EH8 9JZ, UK; kicelandy@gmail.com

8 Research Unit "Induced Resistance and Plant Bioprotection", EA 4707, SFR Condorcet FR CNRS 3417, Faculty of Sciences, University of Reims, PO Box 1039, CEDEX 2, 51687 Reims, France; philippe.jeandet@univ-reims.fr

9 Department of Medical Microbiology and Immunology, Faculty of Medicine, Assiut University, Assiut 71515, Egypt

10 Department of Internal Medicine, University of Cincinnati College of Medicine, Clifton Ave, Cincinnati, $\mathrm{OH} 45221$, USA

* Correspondence: gaberbatiha@gmail.com (G.E.-S.B.); amanimagdi2008@gmail.com (A.M.B.); helal.hetta@uc.edu (H.F.H.)

+ These authors contributed equally.

Received: 15 June 2020; Accepted: 21 July 2020; Published: 22 July 2020

\begin{abstract}
Pepper originated from the Capsicum genus, which is recognized as one of the most predominant and globally distributed genera of the Solanaceae family. It is a diverse genus, consisting of more than 31 different species including five domesticated species, Capsicum baccatum, C. annuиm, C. pubescen, C. frutescens, and C. chinense. Pepper is the most widely used spice in the world and is highly valued due to its pungency and unique flavor. Pepper is a good source of provitamin A; vitamins E and C; carotenoids; and phenolic compounds such as capsaicinoids, luteolin, and quercetin. All of these compounds are associated with their antioxidant as well as other biological activities. Interestingly, Capsicum fruits have been used as food additives in the treatment of toothache, parasitic infections, coughs, wound healing, sore throat, and rheumatism. Moreover, it possesses antimicrobial, antiseptic, anticancer, counterirritant, appetite stimulator, antioxidant, and
\end{abstract}


immunomodulator activities. Capsaicin and Capsicum creams are accessible in numerous ways and have been utilized in HIV-linked neuropathy and intractable pain.

Keywords: bioactive constituents; Capsicum spp.; pharmacokinetics

\section{Introduction}

Chili peppers originated after the Columbian Exchange in Mexico; various types of chili pepper spread through the planet, employed in the diet and as a traditional medicine [1]. Pepper (Capsicum spp.) is among the oldest cultivated and most employed crops. Its usage started quite a long time ago and it is considered to have its source in America [2,3]. The genus Capsicum contains over 200 species, with the fruits differing extensively in taste and olfactory heat. Five principal Capsicum types mentioned in published works include: Capsicum annuum, C. baccatum, C. chinense, C. frutescens, and C. pubescens. Peppers from Capsicum species are natural to the tropical and humid zones of Central and South America and incorporate peppers of significant financial importance [4,5]. They are generally employed as condiments or nutrients, with a wide range of beneficial use in Indian, American, and Chinese therapeutic customs for the treatment of acne, inflammation of the joints, and indigestion [6]. Pepper belongs to the genus Capsicum, which is an associate of the Solanaceae family. The genus Capsicum contains roughly 31 types, of which the major five cultivated types are C. annuum, C. baccatum, $C$. chinense, C. frutescens, and C. pubescens. C. frutescens and C. chinense are now widely cultivated [3]. Pepper is the most generally utilized seasoning sauce globally and is markedly valued for its spiciness and adds exceptional savor to numerous dishes all over the world. In the past, it was utilized primarily for flavorings and as a therapeutic plant, but nowadays its usage has expanded to crisps, prepared vegetables, and flavorings; it is reared as a decorative plant; and it is used in the preparation of extracts for numerous medicinal and make-up businesses [7,8]. The normal weekly family intake of dry pepper is projected at $140 \mathrm{~g}$. It is taken as fine particles processed from dry pods called "berbere" and mixed with dishes as a food and flavor. The pods are the major constituents for processing "shiro" powder, recognized as a common condiment [9]. Herbal medicine remains generally exercised in major emerging countries, whereas the process of employing alternate medicine is rapidly cumulative $[10,11]$. In Eritrea, the usage of herbal medicine is comparable to several countries with copious therapeutic traditions in numerous situations [12,13]. Pepper is a major plant employed as medication over time in several countries. In ancient times, it was employed for managing respiratory disease and alleviating toothaches [3]. In accordance with the World Health Organization, inquiries about its toxicity, safety, potency, value, accessibility, protection, and additional improvement are required. It was revealed that about 4 out of 10 people in the UK employ alternative medicine sometimes in their lives [14]. Therefore, the aim of this work is to focus on the nutritional value, morphology and extraction procedures as well as the therapeutic properties and uses, recommended doses, toxicity, and pharmacokinetics of chili pepper.

\section{Morphology and Extraction Procedures}

C. annuum, which is a suffrutescent annual shrub, grows up to $0.75-1.8 \mathrm{~m}$ in cultivated locations with many angular twigs. The leaves are simple and are of different shapes, and alternate, elliptical to lanceolate, with smooth margins (entire) that are usually wrinkled. The small flowers (around 1.5 or $1 \mathrm{~cm}$ in diameter) are white or violet, in groups of two or more. The fruits are many-seeded berries which may be long, cylindrical, ovoid, obtuse, or oblong, but with no sutures; they are red when ripe, with a smooth shiny surface. The fruit is up to $25 \mathrm{~cm}$ in length and $7 \mathrm{~mm}$ in breadth, with many seeds which are yellow, smooth, round, and discoid, with a protuberant spine-aroma on the edge. C. annuum fruits have a characteristic odor and pungent taste [15]. Several extraction procedures of capsaicinoids from hot peppers have been established in the past few years. When 
planning an extraction procedure, the initial step is the choice of a suitable solvent that would give a good yield of the preferred compound. Amongst the solvents employed for extracting capsaicinoids, methanol, ethanol, acetonitrile, and water are the most common solvents [16]. Furthermore, in the solvent choice process, numerous other prompting factors are deliberated to attain a high extraction productivity-for example, the temperature, time of extraction, solvent volume, sample quantity, and the replicability and reproducibility of the procedures. The methods that are extensively used by researchers include maceration [17], magnetic stirring [18], enzymatic extraction [19], microwave- [20] and ultrasound-assisted extraction (UAE) [21], Soxhlet (SOX) [22], supercritical fluid [23], and pressured liquids extraction (PLE) [24]. The general extraction procedures for capsaicinoids are discussed in the following.

\subsection{Enzymatic Treatment}

Enzymatic approaches are suggested to increase the yield of compounds extracted from fruits [25]. The study conducted by Santamaria et al. [19] reported that a number of commercially available enzymes were used to separate chili pepper tissues and increase yields by $7 \%$, with a final recovery of $80 \%$ of capsaicinoids. Recently, a comparable treatment protocol was espoused by Desikacharya et al. [26] via extrazyme (mainly pectinase and multiple carbohydrases) and energex (mainly glucanase), which augmented the capsaicinoid yield by $32 \%$. In accordance with the treatment protocols specified above, Salgado-Roman et al. [27] projected a nonsalable enzymatic action via the enzymatic extracts obtained from Rhizopus nigricans.

\subsection{UAE (Ultrasound-Assisted Extraction)}

The UAE method is productive owing to the occurrence of cavitation, which happens once an ultrasonic wave transients via an organic solvent, generating energy to improve the mixing and diffusion of the solvent into the sample matrix [21]. The functions of UAE offer numerous merits, for example the reduction in the solvents, temperature, and time needed for extraction, which is vital for the extraction of thermolabile and unstable compounds [28] Barbero et al. [18] established a fast-replicated UAE protocol for capsaicinoids from three types of peppers.

\subsection{Soxhlet (SOX) Extraction}

The SOX process is an orthodox technique that is extensively helpful in removing oil from the matrix, which is utilized when the compound of interest has restricted solubility in a solvent while the impurities are insoluble in the solvent [22]. Bajer et al. [29] extracted capsaicinoids from several chili samples via the SOX procedure, with methanol as the solvent and an extraction time of $2 \mathrm{~h}$. The same SOX procedure was utilized in a study by Liu et al. [30], in which the extraction of $1.0 \mathrm{~g}$ of a C. annuum sample was achieved with $50 \mathrm{~mL}$ of methanol for $2 \mathrm{~h}$.

\subsection{Supercritical Fluid Extraction (SFE)}

Supercritical fluids are constituents at pressures and temperatures above their critical values and are powerful solvents for nonpolar compounds [31]. After the pressure is attuned to ambient pressure, the supercritical fluids return to the gas phase and vaporize without leaving solvent residues. Supercritical fluid extraction (SFE) is utilized as an alternate to the orthodox procedure during the extraction of bioactive compounds, with the benefit of moderate temperatures, decreased energy consumptions, and high-purity extracts [32]. Carbon dioxide $\left(\mathrm{CO}_{2}\right)$ is regularly utilized as the supercritical solvent for capsaicinoids because it is cheap, nontoxic, nonflammable, and inert and has a high extraction capacity $[23,33,34]$. Capsaicinoid extraction from the malagueta pepper (C. frutescens L.) can be performed via SFE aided by ultrasound with $\mathrm{CO}_{2}$ as the solvent at the pressure, temperature, and flow rate of $15 \mathrm{MPa}, 40{ }^{\circ} \mathrm{C}$, and $1.673 \times 10^{-4} \mathrm{~kg} / \mathrm{s}$, respectively [35]. The improved SFE rate was attained when the ultrasound power was maintained at 360 watts for $60 \mathrm{~min}$. Later in 2016, Dias et al. [32] accomplished a similar SFE test on dedo de moça pepper with $25 \mathrm{MPa}, 40^{\circ} \mathrm{C}, 600 \mathrm{~W}$, 
and $80 \mathrm{~min}$ and without $25 \mathrm{MPa}, 40{ }^{\circ} \mathrm{C}$. The results revealed that the universal yield of SFE was productively improved.

\subsection{PLE (Pressurized Liquids Extraction)}

The process of PLE is regularly performed at a raised temperature and pressure, allowing the high solubility of the compound in the solvent whilst maintaining the solvent beneath its boiling point, and thus leading to a high permeation of the solvent into the sample matrix [24,36]. Many scientists have espoused the PLE technique [29,30,37]. Barbero et al. [37] improved a PLE protocol with the extraction solvent of water, methanol, and ethanol with a temperature of $200{ }^{\circ} \mathrm{C}$ and pressure of $100 \mathrm{~atm}$.

\subsection{MAE (Microwave-Assisted Extraction)}

The method of microwave-assisted extraction (MAE) is performed via the mixture of microwaves and a conventional solvent that employs energy production in numerous experiments $[20,38,39]$. In agreement with Williams et al. [20], the capsaicinoids yielded via the MAE technique multiplied and the time was considerably reduced when associated with the conventional reflux and jarring flask extraction procedures. The MAE requirements for the extraction of capsaicinoids from fresh pepper samples were enhanced by Barbero et al. [38]. The authors also compared it to the extraction effectiveness of generally utilized protocols—for example, magnetic stirring —and established that MAE is a much quicker technique. Chuichulcherm et al. [39] made an evaluation of three diverse extraction procedures (SOX, MAE, and UAE).

\section{Chemical Constituents}

\subsection{Capsicum Annuum}

The chemical composition of $C$. annuum fruits include dry matter, total fat, protein, carbohydrates, dietary fibers, vitamin C, calories, and energy [40]. Zaki et al. [40] determined the nutritional and biochemical constituents of $C$. annuum fine particles (dry weight, DW) at diverse harvest periods (December, November, October, and September), as shown in Table 1. However, the mineral constituents of the oils extracted from two varieties of $C$. annuum (sweet and bell pepper) are shown in Table 2 [41].

Table 1. Nutritional and biochemical constituents of $C$. annuum fine particles at diverse harvest periods.

\begin{tabular}{cc}
\hline Nutritional and Biochemical Constituents & Value \\
\hline Carbohydrate & $55.33 \pm 4.8-55.96 \pm 3.3$ \\
Protein & $20.19 \pm 2.6-21.50 \pm 4.5$ \\
Lipid & $7.55 \pm 3.9-9.75 \pm 3.3$ \\
Dietary fiber & $35.05 \pm 1.4-37.07 \pm 3$ \\
Total sugar & $6.88 \pm 0.47-11.19 \pm 0.11$ \\
Energy content & $1449.55-1573.17$ \\
Vitamin C & $1360.2 \pm 14.3-2020 \pm 32.3$ \\
Total capsaicinoids & $24.8 \pm 5.5-59.7 \pm 6.2$ \\
Scoville heat value & $73-938$ \\
Potassium & $2168 \pm 147-2523 \pm 280$ \\
Phosphorus & $363 \pm 43-453 \pm 30$ \\
Magnesium & $130 \pm 15-146 \pm 49$ \\
Calcium & $41.62 \pm 10-186 \pm 54$ \\
Iron & $31 \pm 10-53 \pm 15$ \\
Sodium & $30 \pm 4-71 \pm 9 ;$ \\
Copper & $1.06 \pm 0.5-1.31 \pm 0.3$ \\
Zinc & $1.67 \pm 0.2-2 \pm 0.2$ \\
\hline
\end{tabular}


Table 2. The mineral constituents of oils extracted from two varieties of C. annuum (sweet and bell pepper).

\begin{tabular}{cccc}
\hline \multicolumn{2}{c}{ Sweet Pepper } & \multicolumn{2}{c}{ Bell Pepper } \\
\hline Mineral Constituent & Value & Mineral Constituent & Value \\
\hline Sodium & $40 \pm 0.01$ & Sodium & $6.10 \pm 0.01$ \\
Calcium & $8.00 \pm 0.01$ & Calcium & $6.00 \pm 0.02$ \\
Magnesium & $9.60 \pm 0.01$ & Magnesium & $6.00 \pm 0.01$ \\
Potassium & $43.70 \pm 0.13$ & Potassium & $49.10 \pm 0.06$ \\
Zinc & $0.01 \pm 0.00$ & Zinc & $0.02 \pm 0.00$ \\
Iron & $9.00 \pm 0.01$ & Iron & $17.10 \pm 0.00$ \\
Cadmium & $\mathrm{ND}$ & Cadmium & $\mathrm{ND}$ \\
Nickel & $\mathrm{ND}$ & Nickel & ND \\
Copper & $0.30 \pm 0.00$ & Copper & $0.16 \pm 0.00$ \\
\hline
\end{tabular}

ND: not determined.

The fruits of $C$. annuum contained capsaicinoids, a kind of bioactive compound that provide a distinctive sharp taste. Two main capsaicinoids, capsaicin and dihydrocapsaicin, were accountable for $90 \%$ of the total sharp strong taste of pepper fruits. In addition to capsaicin and dihydrocapsaicin, at least nine insignificant capsaicinoids have been revealed to appear in peppers [42]. Capsaicin $\left(\mathrm{C}_{18} \mathrm{H}_{27} \mathrm{NO}_{3}\right)$ is identified with numerous alternative expressions-i.e., $\quad N$-[(4-hydroxy-3-methoxybenzyl]-8-methyl-trans-6-nonenamide, $N$-[(4- hydroxy-3-methoxy-phenyl)methyl]-8-methyl-trans-6-nonenamide, $N$-(3-methoxy-4-hydroxy benzyl)-8-methylnon- trans-6-enamide, trans-8-methyl- $N$-vanillyl-6- nonenamide, isodecenoic acid vanillylamide, and 8-methylnon-6-enoyl-4-hydroxy-3-methoxy benzylamide. Capsaicin is a decylenic acid amide of vanillyl-amine. On the alteration in the acid part of the particle, a dissimilar grade of sharpness of analogues has been perceived [43,44]. Capsaicin is an odorless white crystal with an intense sharpness. One part in 100,000 can be sensed by tasting. It has a molecular weight of $305.4118 \mathrm{~g} / \mathrm{mol}$, a melting point of $65^{\circ} \mathrm{C}$, a boiling point at $0.01 \mathrm{~mm} \mathrm{Hg}$ of $210-220^{\circ} \mathrm{C}$, a sublimate at $115^{\circ} \mathrm{C}$, a UV max at 227 and $281 \mathrm{~nm}$, and is faintly soluble in carbon disulfide and hot water [45]. The capsaicin level of the fruits is principal in the burning taste of several kinds of Capsicum sp. The capsaicin content was determined in 12 types of edible capsicum in different areas in Indonesia. The results indicated that green paprika, yellow paprika, and red paprika do not contain capsaicin [46]. The chemical constituents of $n$-hexane extracts from $C$. annuum at diverse phases of maturing (red, green, and small green) are shown in Table 3 [47]. Nine compounds were observed in the flavonoid and phenolic acid fraction, as shown in Table 4. 
Table 3. Chemical constituents of $n$-hexane $C$. annuum extracts.

\begin{tabular}{|c|c|c|}
\hline Compounds & Compounds & Ref. \\
\hline 2-heptanal $(E)$ & 2-decenal $(E)$ & \\
\hline$(2 E, 4 E)$ 2,4-decadienal & Cadienal & \\
\hline 2-undecenal & Tetradecane & \\
\hline Methyl 9-oxononanoate & Hexadecane & \\
\hline 2,6,10,14-tetramethyl & Pentadecane & \\
\hline Phenol & 2,6-bis(1,1-dimethylethyl)-4-methyl & \\
\hline Heptacosane & Farnesol & \\
\hline Hexadecene & Tetradecanal & \\
\hline Heptadecane & Myristic acid methyl ester & \\
\hline 9-octadecene $(E)$ & 1-pentadecene & \\
\hline Undecane & Exadecane & \\
\hline Oleic acid & Oleic acid methyl ester & \\
\hline Pentadecanoic acid methyl ester & Pentadecanoic acid & \\
\hline Neophytadiene & 2-pentadecanone, 6,10,14-trimethyl & \\
\hline 2-decene, 7-methyl- & Palmitic acid, 14-methyl- methyl ester & \\
\hline (Z) pentadecanoic acid & Palmitic acid ethyl ester & \\
\hline Margaric acid methyl ester & 5-octadecene $(E)$ & \\
\hline 1-octadecadienoic acid methyl ester & Linolenic acid methyl ester & [47-49] \\
\hline Phytol, stearic acid methyl ester & Hexadecanamide & \\
\hline Eicosane & Octadecanal & \\
\hline Nonadecanoic acid methyl ester & 1-octadecene & \\
\hline Linoleic acid & Docosane & \\
\hline Arachidic acid methyl ester & Octadecane & \\
\hline 9-octadecenamide (Z)-1-heneicosyl formate & Octadecanamide & \\
\hline Heneicosanoic acid methyl ester & Cyclodocosane ethyl & \\
\hline 4-hexenoic acid, 3-methyl-2,6-dioxo- & Cyclotetracosane & \\
\hline Behenic acid methyl ester & Palmitic acid 2-hydroxy-1-(hydroxymethyl) ethyl ester & \\
\hline Pelargonic acid vanillylamide & Linoleic acid 2-hydroxy-1-(hydroxymethyl) ethyl ester & \\
\hline Tricosanoic acid methyl ester & 2-monolinolenin & \\
\hline Stearic acid & 2-hydroxy-1-(hydroxymethyl) ethyl ester & \\
\hline Cholest-5-en-3-ol (3ß) & Lignoceric acid methyl ester & \\
\hline Ergost-5-en-3-ol, $(3 \beta, 24 R)$ - & Vitamin E & \\
\hline Stigmast-5,22-dien-3-ol $(3 \beta, 22 E)$ & Stigmast-5-en-3-ol, $(3 \beta, 24 S)$ & \\
\hline$\beta$-Amyrin & Viminalol & \\
\hline Stigmast-4-en-3-one & & \\
\hline
\end{tabular}


Table 4. The flavonoid and phenolic acid fraction of red pepper extract.

\begin{tabular}{|c|c|c|}
\hline Compounds & Compounds & Ref. \\
\hline trans- $p$-feruloyl- $\beta$-D-glucopyranoside; & trans- $p$-sinapoyl- $\beta$-D-glucopyranoside & \multirow{5}{*}[50-53]{} \\
\hline Quercetin 3-O- $\alpha$-L-rhamnopyranoside-7-O- $\beta$-D-glucopyranoside & Luteolin 6-C- $\beta$-D-glucopyranoside-8-C- $\alpha$-L-arabinopyranoside & \\
\hline $\begin{array}{l}\text { trans-p-feruloyl alcohol-4-O-[6-(2-methyl-3-hydroxypropionyl] } \\
\text { glucopyranoside }\end{array}$ & Apigenin $6-C-\beta$-D-glucopyranoside- 8 - $C$ - $\alpha$-L-arabinopyranoside; & \\
\hline Lutoeolin 7-O-[2-( $\beta$-D-apiofuranosyl)- $\beta$-D-glucopyranoside] & $\begin{array}{l}\text { Quercetin 3-O- } \alpha \text {-L-rhamnopyranoside and } \\
\text { luteolin-7-O-(2-apiofuranosyl-4-glucopyranosyl-6-malonyl) } \\
\text { glucopyranoside. }\end{array}$ & \\
\hline Quercetin-3-O-L-rhamnoside & & \\
\hline
\end{tabular}


The key compounds of this fraction obtained from red pepper were sinapoyl and feruloyl glycosides, and the major compound from green pepper was quercetin-3-O-L-rhamnoside [50]. The leaves contain alkaloids, tannins, and flavonoids [51], whereas the roots contain steroids, alkaloids, coumarins, glycosides, and triterpenoids [52]. Ten sesquiterpenoids were isolated from the ethyl acetate soluble fraction of the methanolic extract of the dried stems and roots of $C$. annuum [53]. C. annuum contained a considerable quantity of L-asparaginase. The enzyme purified from the plant enzyme existed in two ways, only one with antitumor activity. The purified enzyme has a molecular weight of 120,000 \pm 500 . The $N$-terminal and the $C$-terminal amino acids residues are alanine and phenylalanine. The enzyme has indivisible glutaminase activity and urease activity [54].

\subsection{Capsicum Frutescens}

Many bioactive compounds were isolated from C. frutescens, including essential oils, alkaloids, glycosides, phenolic compounds, flavonoids, esters, terpenoids, noncarotenoids, lipoxygenase derivatives, carbonyls, alcohols, hydrocarbons, hydroxybenzoic acid, hydroxycinnamic acid, ascorbic acid, tannins, steroids, capsaicin, dihydrocapsaicin, capsiconinoids, capsinoids, ortho-hydroxy- $N$-benzyl-16- methyl-11,14-diene-octadecamide, and 9 and 12-diene-octadecanoic acid. Capsinoids are non-pungent capsaicin-related compounds derived from the $\mathrm{CH}-19$ sweet pepper of all varieties of the Capsicum genus. Capsiate, dihydrocapsiate, and nordihydrocapsiate are three capsinoids structurally similar to the pungent capsaicins, dihydrocapsaicin and nordihydrocapsaicin, which are, respectively, the bioactive constituents of Capsicum, except for the fact that their two moieties are connected by an ester bond instead of an amide bond [55]. However, the capsaicinoids (vanillylamides of monocarboxyl acids) which are accountable for the sharpness are believed to be the bioactive compounds in the plants' fruits [56,57].

\section{Evaluation of Biochemical Composition}

C. annuum fruits are rich in capsaicinoids, carotenoids, flavonoids, vitamins, and minerals (Table 5). Studies conducted in the last 50 years have contributed in discovering the type and the percentage of the main chemical constituents in the plants of this species. The composition and quantity of these compounds vary according to the genotype; moreover, other factors-e.g., the fruit ripening and the cultivation system-could influence the composition. From a genetic perspective, the occurrence/nonappearance of capsaicinoids varies in the fruit placenta, while the alternative presence of three recessive alleles (pun 1, pun $1^{2}$, pun $1^{3}$ ) determine the absence of these compounds. These metabolites could be a natural defense against biotic and abiotic mechanisms [58]. Furthermore, the presence of other phytochemical substances is favorable for the plant and for the human being; for example, the antioxidant activities of polyphenols, such as flavonoids and cinnamic acid derivates, could be a gastric protector in the human and animal diet. Capsaicin (also called 8-metil- $\mathrm{N}$-vanillil-6-noneamide, $\mathrm{C}_{16} \mathrm{H}_{27} \mathrm{NO}_{3}$ ) and diidrocapsaicin are responsible for $90 \%$ of the spice [59]. Both, together with other minor capsaicinoids, such as omodiidrocapsaicin, nordiidrocapsaicin, and omocapsaicin, are the major end products of the metabolic pathway that allows the synthesis of these compounds throughout vanillylamide condensation with branched short chain fatty acids. The capsaicin is the most powerful natural compound, with a pungent, painful, and desensitizing effect, since its structure has an ammidic bond and a double bond (linked to an ether). Variations in one or more groups (chain length, branches, etc.) indicate the intensity of the desensitization. Capsaicinoids, which are synthesized in the fruit placenta after enzymatic condensation, are alkaloid, which confers to the fruits a strong and pungent taste that is popular as a spice; they are characterized by the presence of a nitrogen atom. This atom is not part of a heterocyclic ring, like the other alkaloid alkaloids; for this reason, the capsaicinoids are classified as proto-alkaloids or pseudo-alkaloids [60]. As the fruits ripen, the capsaicinoids start to increase. The seeds do not yield capsaicin, but they can recover it from tissues of the plant that surround them. Capsaicin and other capsaicinoids are stable alkaloids-they stay intact also after cooking and thawing 
for a long period. Capsaicinoids and capsaicin produce a stinging feeling in mammals, including humans, and produce a burning sensation in the mucosa and the mouth, where they stimulate the VR1 receptors (Vanilloid Receptor type 1). These receptors activate the VRL-1 (Vanilloid receptor-like) protein synthase, the enzyme which produces capsaicinoids and catalyzes the reactions that produce two metabolites: vanilalanine (a biosynthetic type of phenilpropanoid) and 8-methyl-6-nonenone (a biosynthetic type of valine). Activated capsaicin connects specific membrane receptors (vanilloid receptor) located on primary afferent nerves. They cause a flow of calcium ions, which depolarize nervous fibres and send nervous pulses to the brain, provoking pain. After the initial excitation, which provokes the burning sensation, during a period of analgesia the neuron cannot answer to any nociceptive stimulus. Secondary metabolites of the phenolic group are synthetized from the plant during stress conditions. Piperine is an $N$-acylpiperidine that belongs to the vanilloid family of compounds, including capsaicin, with an antimutagenic activity. Recently, they have been studied by researchers, as they are antioxidants and can protect organisms from free radicals produced during the cell metabolism. Several studies have tried to evaluate the presence and the dose of phenols in plants of the Capsicum genus. Among them, Sukrasno et al. [61] highlighted the presence of two flavonoids-3-O-ramnosilquercetin and 7-O-glucosilluteolin-and three acid cinnamic derivatives: glucoside p-cumaroyl-cinnamoyl, glucoside caffeoyl-cinnamoyl, and 3,4-dimethoxycinnamoyl glycoside. Other researchers have evaluated the composition of two flavonoids (quercetin and luteolin) after the acid hydrolysis of a phenolic portion of a C. annuum extract [62]. Loizzo et al. [63] achieved a detailed analysis of a phenolic chili pepper portion and identified 10 compounds. Three of them were new: capsiosid A, capsiosid B, and capsianosid VII. Other phenols in plants of the Capsicum genus have been reported, including trans- $p$-feruloyl- $\beta$-D-glucopyranoside, trans- $p$-sinapoyl D-glucopyranoside, apigenin 6-C-D-glucopiranoside-8- $C$-L-arabinopiranoside, D-glucopyranoside, quercetin 3-O-L-ramnopyranoside-7-O-D-glucopyranoside, quercetin 3-O-L-ramnopiranoside, luteolin 7-O-[2-D-apiofuranosyl)-4-D-glucopyranosyl)-6-malonyl-D-glucopyranoside, luteolin 6-O-D-glucopyranosyl-8-C-L-arabinopyranoside, and luteolin-7-O-[2-D-(apiofuranosyl)- $\beta$ D-glucopyranoside] [59]. Flavonoids are the other compound with an antioxidant property. They stop the activity of some enzymes, such as prostaglandin synthase, lipoxygenase, and cyclooxygenase, which are involved in cancer genesis. In fruits and plants, they are glycosides, with a sugar linked to 3-carbon. They are degraded to aglycones after ingestion. Quercetin and luteolin are the principal polyphenolic flavonoids found in C. annuиm. Carotenoids are responsible for the product color, and they are at epicarp. The coloring is the result of more than 30 types of carotenoids: capsanthin and capsorubin are accountable for the red color, while the yellow shade is given by xanthophylls and carotenes. All the carotenoids in chili peppers are isoprenoids with 40 carbon atoms and contain nine double bonds in the central chain; the diverse final groups $(b, e, k$, 3-idrossi-5, 6-eposide) contain the modification chromophore properties of all pigments, permitting their classification into two isochromatic families: red $(\mathrm{R})$ and yellow $(\mathrm{Y})$. The red portion is rich in capsanthin, capsanthin-5,6-episode capsorubin (together with other minor carotenoids), while the yellow portion consists of all the other pigments (principally zeaxanthin, violaxanthin, anteraxanthin, $\beta$-cryptoxanthin, $\beta$-carotene, cucurbitaxanthin A). $\beta$ - Carotene is a naturally occurring retinol (vitamin A) precursor obtained from certain fruits and vegetables with potential antineoplastic and chemopreventive activities. Peppers are also a rich supply of oxygenate carotenoids, which differ in components and concentration according to their genetics and ripening grade [64]. From dry chili peppers, it is possible to extract an oleoresin, which is used as a food dye. Peppers are also riches in vitamins [65]. Vitamins are essential organic compounds. They must be taken daily with the diet in small amounts, as they are not synthetized by the organism. In the Capsicum genus, the plants are abundant in vitamins A, C, E, D, and B [66]. Ascorbic acid has antioxidant properties in biologic organisms and restricts worsening processes [67]. Ascorbic acid is the primary molecule that is biologically active, but deidroascorbic acid is important for humans because it is easily transformed into ascorbic acid. 
Table 5. International Union of Pure and Applied Chemistry (IUPAC) name, and the chemical formula of bioactive molecules isolated from Capsicum.

\begin{tabular}{|c|c|c|c|c|c|c|}
\hline Compound & Synonyms & Class of Compound & IUPAC Name & Chemical Formula & Examples of Plants Parts as Source & Ref. \\
\hline Piperine & 1-Piperoylpiperidine & $\begin{array}{l}\text { Piperine is a } N \text {-acylpiperidine that is piperidine } \\
\text { substituted by a } \\
(1 E, 3 E)-1-(1,3-\text {-benzodioxol-5-yl)-5-oxopenta-1,3-dien-5-yl } \\
\text { group at the nitrogen atom. }\end{array}$ & $\begin{array}{l}\text { (2E,4E)-5-(1,3-benzodioxol-5-yl)-1- } \\
\text { piperidin-1-ylpenta-2,4-dien-1-one }\end{array}$ & $\mathrm{C}_{17} \mathrm{H}_{19} \mathrm{NO}_{3}$ & Constituent of pepper spp. (Piperaceae). & {$[68]$} \\
\hline Capsaicin & Capsaicin & $\begin{array}{l}\text { Capsaicin is a capsaicinoid. It has a role as a non-narcotic } \\
\text { analgesic, a voltage-gated sodium channel blocker, and a } \\
\text { TRPV1 agonist. }\end{array}$ & $\begin{array}{l}\text { (E)-N-[(4-hydroxy- } \\
\text { 3-methoxyphenyl)methyl]-8- } \\
\text { methylnon-6-enamide }\end{array}$ & $\mathrm{C}_{18} \mathrm{H}_{27} \mathrm{NO}_{3}$ & $\begin{array}{l}\text { Capsaicin is identified as the primary } \\
\text { pungent principle in Capsicum fruits. }\end{array}$ & {$[60]$} \\
\hline Dihydrocapsaicin & 6,7-Dihydrocapsaicin & $\begin{array}{l}\text { Dihydrocapsaicin is a capsaicinoid and analog and } \\
\text { congener of capsaicin in chili peppers (Capsicum). Like } \\
\text { capsaicin, it is an irritant. }\end{array}$ & $\begin{array}{l}\text { N-[(4-hydroxy-3- } \\
\text { methoxyphenyl)methyl]- } \\
\text { 8-methylnonanamide }\end{array}$ & $\mathrm{C}_{18} \mathrm{H}_{29} \mathrm{NO}_{3}$ & $\begin{array}{l}\text { Dihydrocapsaicin is found in pepper } \\
\text { (C. annum). }\end{array}$ & [69] \\
\hline Nordihydrocapsaicin & $\begin{array}{l}\text { N-(4-hydroxy-3-methoxybenzyl)- } \\
\text { 7-methyloctanamide }\end{array}$ & Nordihydrocapsaicin is found in herbs and spices. & $\begin{array}{l}N \text {-[(4-hydroxy-3- } \\
\text { methoxyphenyl)methyl]- } \\
\text { 7-methyloctanamide }\end{array}$ & $\mathrm{C}_{17} \mathrm{H}_{27} \mathrm{NO}_{3}$ & $\begin{array}{l}\text { Nordihydrocapsaicin is isolated from the } \\
\text { pungent principle of red pepper (Capsicum } \\
\text { annuum). }\end{array}$ & [69] \\
\hline Capsiate & $\begin{array}{l}\text { (4-hydroxy-3-methoxyphenyl)methyl } \\
\text { (E)-8-methylnon-6-enoate }\end{array}$ & Lipophilic alkaloid is an analogue of capsaicin. & $\begin{array}{l}\text { (4-hydroxy-3-methoxyphenyl)methyl } \\
\text { (6E)-8-methylnon-6-enoate }\end{array}$ & $\mathrm{C}_{18} \mathrm{H}_{26} \mathrm{O}_{4}$ & $\begin{array}{l}\text { Non-pungent capsaicin-related substances } \\
\text { found in all tested variants of the Capsicum } \\
\text { genus of plants. }\end{array}$ & {$[70]$} \\
\hline Dihydrocapsiate & $\begin{array}{l}\text { 4-Hydroxy-3-methoxybenzyl } \\
\text { 8-methylnonanoate }\end{array}$ & Lipophilic alkaloid is an analogue of capsaicin. & $\begin{array}{l}\text { (4-hydroxy-3-methoxyphenyl)methyl } \\
\text { 8-methylnonanoate }\end{array}$ & $\mathrm{C}_{18} \mathrm{H}_{28} \mathrm{O}_{4}$ & $\begin{array}{l}\text { Non-pungent capsaicin-related substances } \\
\text { found in all tested variants of the Capsicum } \\
\text { genus of plants. }\end{array}$ & {$[70]$} \\
\hline Nordihydrocapsiate & $\begin{array}{l}\text { 4-hydroxy-3-methoxybenzyl 7- } \\
\text { methyloctanoate }\end{array}$ & Lipophilic alkaloid is an analogue of capsaicin. & $\begin{array}{l}\text { (4-hydroxy-3-methoxyphenyl)methyl } \\
\text { 7-methyloctanoate }\end{array}$ & $\mathrm{C}_{17} \mathrm{H}_{26} \mathrm{O}_{4}$ & $\begin{array}{l}\text { Non-pungent capsaicin-related substances } \\
\text { found in all tested variants of the Capsicum } \\
\text { genus of plants. }\end{array}$ & [70] \\
\hline Capsiconiate & Coniferyl (E)-8-methyl-6-nonenoate & Secondary plant non-toxic alkaloid metabolites. & $\begin{array}{l}{[(E)-3 \text {-(4-hydroxy-3-methoxyphenyl)prop- }} \\
\text { 2-enyl] (E)-8-methylnon-6-enoate }\end{array}$ & $\mathrm{C}_{20} \mathrm{H}_{28} \mathrm{O}_{4}$ & $\begin{array}{l}\text { Non-pungent capsaicin-related substances } \\
\text { found in all tested variants of the Capsicum } \\
\text { genus of plants. }\end{array}$ & {$[71]$} \\
\hline Dihydrocapsiconiate & Coniferyl 8-methylnonanoate & Secondary plant non-toxic alkaloid metabolites. & $\begin{array}{l}\text { 3-(4-hydroxy-3-methoxyphenyl)prop- } \\
\text { 2-en-1-yl 8-methylnonanoate }\end{array}$ & $\mathrm{C}_{20} \mathrm{H}_{30} \mathrm{O}_{4}$ & $\begin{array}{l}\text { Non-pungent capsaicin-related substances } \\
\text { found in all tested variants of the Capsicum } \\
\text { genus of plants. }\end{array}$ & {$[71]$} \\
\hline beta-Carotene & Provitamin A & $\begin{array}{l}\beta \text { - Carotene is a naturally-occurring retinol (vitamin A) } \\
\text { precursor obtained from certain fruits and vegetables with } \\
\text { potential antineoplastic and chemopreventive activities. } \\
\text { As an anti-oxidant, beta carotene inhibits free-radical } \\
\text { damage to DNA. }\end{array}$ & $\begin{array}{l}\text { 1,3,3-trimethyl-2-[(1E,3E,5E,7E,9E,11E, } \\
13 E, 15 E, 17 E)-3,7,12,16 \text {-tetramethyl-18- } \\
\text { (2,6,6-trimethylcyclohexen-1-yl)octadeca- } \\
1,3,5,7,7,911,13,15,17-\text {-nonaenyl]cyclohexene }\end{array}$ & $\mathrm{C}_{40} \mathrm{H}_{56}$ & Fruits. & {$[72,73]$} \\
\hline Rutin & Quercetin 3-rutinoside & $\begin{array}{l}\text { Rutin is a flavonoid known to have a variety of biological } \\
\text { activities, including antiallergic, anti-inflammatory, } \\
\text { antiproliferative, and anticarcinogenic properties. }\end{array}$ & $\begin{array}{l}\text { 2-(3,4-dihydroxyphenyl)-5,7-dihydroxy-3- } \\
{[(2 S, 3 R, 4 S, 5 S, 6 R)-3,4,5 \text {-trihydroxy-6- }} \\
{[[(2 R, 3 R, 4 R, 5 R, 6 S)-3,4,5 \text {-trihydroxy-6- }} \\
\text { methyloxan-2-yl]oxymethyl]oxan-2- } \\
\text { yl]oxychromen-4-one }\end{array}$ & $\mathrm{C}_{27} \mathrm{H}_{30} \mathrm{O}_{16}$ & Pepper fruit. & {$[74]$} \\
\hline Quercetin & Xanthaurine & $\begin{array}{l}\text { Quercetin is a polyphenolic flavonoid with potential } \\
\text { chemopreventive activity. }\end{array}$ & $\begin{array}{l}\text { 2-(3,4-dihydroxyphenyl)-3,5,7- } \\
\text { trihydroxychromen-4-one }\end{array}$ & $\mathrm{C}_{15} \mathrm{H}_{10} \mathrm{O}_{7}$ & Pepper fruit. & {$[50]$} \\
\hline
\end{tabular}




\section{Pharmacological Activity}

\subsection{Traditional Uses}

Capsicum is a humid, significant agrarian crop and one of the most prevalent vegetables, not only due to its financial worth, but for the mixture of the color, taste, and nutritious properties of its fruit $[75,76]$ (Figure 1). The interest in the ingesting of Capsicum is, to a great degree, because of its constituents and significance as a dietary antiradical [4].

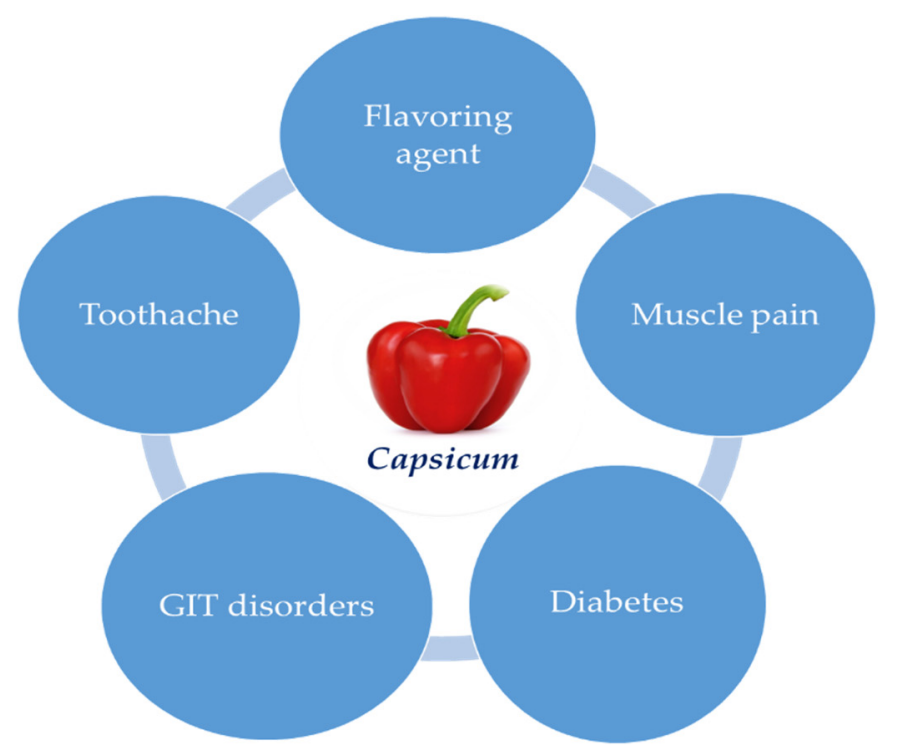

Figure 1. Traditional uses of Capsicum.

Capsicum has been utilized as a colorant, flavorant, and/or as a source of spiciness. The key supply of sharpness in peppers is the functional group of alkaloid components, known as capsaicinoids (CAPS), formed in the fruit. Dried chili is likewise appreciated for its involvement in the taste of chili sauces and chili powders. Its flavoring property is linked to its volatile aromatic compounds and color. As a universal rule, when the color of paprika or chili powder disappears, the flavor also vanishes [4]. Both volatile and non-volatile substances add to its usage as a flavoring agent [77]. C. annuum was used traditionally to cure toothache. The fruits are employed to activate gastric activities and cause an upsurge in blood circulation. It is also a stimulant and carminative, and is utilized traditionally for neuralgia and rheumatism [78,79]. C. frutescens was also utilized locally as an exterior remedy in agonizing muscle pangs. Furthermore, it is also employed for managing hyperglycemia, blood pressure (high/low), bronchitis, and burning feet; to upsurge circulation; to ease rheumatic discomfort; to heal mouth wounds and infested wounds; to decrease blood clots; and to aid ingestion by accelerating the saliva and stomach juice flow [80,81]. Capsaicin and its derivatives were employed topically to cure chronic discomfort syndromes, musculoskeletal pain, and diabetic complications [82,83]. The topical usage of capsaicin induces burning pain and neurogenic inflammation $[84,85]$. The cured area becomes less sensitive to pain after recurrent applications; this outcome has made capsaicin a slightly acting analgesic in chronic painful complains [86,87].

\subsection{Activities Related to Infectious Diseases}

\subsubsection{Antimicrobial Effects}

Capsicum annuum

The butanol extract of C. annuum fruit revealed a great antimicrobial activity compared to verified pathogens, though other extracts have displayed a relatively modest activity. The ethanol 
extract $(100 \mathrm{mg} / \mathrm{mL})$ of $C$. annuum has displayed a relatively great antimicrobial activity against Micrococcus sp $(20 \mathrm{~mm})$, Bacillus $(10 \mathrm{~mm})$, E. Coli $(17 \mathrm{~mm})$, Pseudomonas sp $(16 \mathrm{~mm})$, and Citrobacter sp $(15 \mathrm{~mm})$ [88]. The inhibitory effect of the extract of $C$. annuum bell pepper type was examined against Salmonella typhimurium and Pseudomonas aeruginosa, injected in pulverized beef meat mixed with diverse concentrations of the extract, and stored at $7{ }^{\circ} \mathrm{C}$ for 7 days [89]. The antibacterial activity of $C$. annuum was examined against pathogenic strains acquired from the urinary tract (Klebsiella pneumoniae, Pseudomonas aeruginosa, and E.coli). The diverse concentrations of the plant extracts displayed an antibacterial activity at 5 and $10 \mathrm{mg} / \mathrm{mL}$ against the tried microorganisms [90].

\section{Capsicum frutescens}

C. frutescens exhibited antibacterial and antifungal activities. CAY-1, a novel saponin obtained from C. frutescens, was identified to be potent against 16 diverse fungal strains; its mechanism of action is by rupturing the membrane integrity of fungal cells $[88,91]$. The minimum inhibitory concentration (MIC) of $C$. frutescens was estimated against six strains of Gram-positive (Staphylococcus aureus, Enterococcus faecalis, Bacillus subtilis) and Gram-negative (Escherichia coli, Klebsiella pneumonia, Pseudomonas aeruginosa) bacteria and one yeast strain (Candida albicans), but for all of these microorganisms, the required concentrations were greater than $1000 \mu \mathrm{g} / \mathrm{mL}$ [92].

\subsubsection{Antifungal Effect}

The antifungal properties of $C$. frutescens extracts against four main fungal strains related to groundnut storage (Aspergillus flavus, A. niger, Penicillium sp., and Rhizopus sp.) were examined. The MIC and minimum fungicidal concentration (MFC) of $C$. frutescens extracts were evaluated. The MIC values of the fruit extract decreased compared to the leaf extract. At the MIC, the leaf extract revealed a potent activity against $A$. flavus $(88.06 \%)$, while the fruit extract revealed activity against $A$. niger $(88.33 \%)$ in the well diffusion method. Groundnut seeds treated with $C$. frutescens fruit extract $(10 \mathrm{mg} / \mathrm{mL})$ displayed an advanced rate of fungal inhibition [93]. Moreover, the peptides obtained from chili pepper seeds hindered the development of the yeasts Saccharomyces cerevisiae, Candida albicans, C. parapsilosis, C. tropicalis, Pichia membranifaciens, Kluyveromyces marxiannus, and C. guilliermondii. The peptide fraction displayed a potent fungicidal activity against C. albicans, Saccharomyces cerevisiae, and Schizosaccharomyces pombe, and also fostered numerous morphological differences to C. albicans. It also decreased the glucose-activated acidification of the medium facilitated by the $\mathrm{H}(+)$-ATPase of $S$. cerevisiae cells in a concentration-dependent approach and resulted in the permeabilization of the yeast membrane to the dye SYTOX Green, as established by confocal laser microscopy [94].

\subsubsection{Antiviral Effect}

Hafiz et al. [95] documented the antiviral effects of $C$. annuum crude extracts against herpes simplex virus-1 (HSV-1) and HSV-2 with a low cytotoxic activity. They revealed that this activity was attributed to the presence of several bioactive compounds, including ascorbic acid and B-carotene.

\subsubsection{Insecticidal, Anthelmintic and Larvicidal Effects}

The insecticidal activities of red pepper (C. annuиm L.) fruit powder were examined against Rhyzopertha dominica and Sitophilus granaries. The results revealed that red pepper in low concentrations did not cause complete mortality in two insects after 14 days. It caused a complete reduction in the Fl progeny of $S$. granarius and $R$. dominica at the highest tested dosages [96]. C. annuum and C. frutescens fruit and seed powders were studied in the research center for the regulation of Callosobruchus maculatus (F.) in stowed cowpea and Sitophilus zeamais in stowed maize. C. frutescens and C. annuum seed powder dust were poisonous to C. maculatus and S. zeamais at the rate of $5.0 \mathrm{~g}$ and $7.5 \mathrm{~g}$ per $50 \mathrm{~g}$ of cowpea and of $50 \mathrm{~g}$ maize within $48 \mathrm{~h}$ and $96 \mathrm{~h}$, respectively [97]. The mosquito-repellent effect of $C$. frutescens extracts was studied against $A$. aegypti mosquitoes. The plant parts were air-dried in the shade and crushed to powder. The combination of $C$. frutescens and C. papaya was efficient for $4 \mathrm{~h}$, while that of 
C. frutescens and C. dactylon was efficient for $3 \mathrm{~h}$. The combination of all three extracts was efficient for $4 \mathrm{~h}$, i.e., allotting the same period of defense as the combination of $C$. frutescens and C. papaya. Combinations of extremely repellent extracts are likely to produce high-repelling products, though it is not possible for the repellency of the mixture to be a simple additive product of the repellencies of the constituent extracts [98]. The insecticidal activity of distinct concentrations of the methanol extract of the fruits and leaves of $C$. frutescens was investigated against the 2nd and 3rd instar larvae of A. aegypti. The mortality of the larvae was discovered to be dose-dependent. The fruit extract has displayed an additional killing property compared to the leaf extract. The antiparasitic effect of the aqueous extract of $C$. frutescens against the fish ectoparasite Ichthyophthirius multifiliis was estimated under in vitro and in vivo circumstances. The outcomes in vitro indicated that aqueous $C$. frutescens extracts led to a more than $70 \%$ mortality of I. multifiliis theronts during $4 \mathrm{~h}$ of exposure and considerably decreased the existence of the tomonts and the total number of theronts freed by the tomonts within $22 \mathrm{hhr}$ [99]. In an in vitro study, extracts from the leaves of $C$. annuum resulted in the death of the cercaria of Schistosoma mansoni within $15 \mathrm{~min}$. The active principles appeared to be water-soluble unsaturated compounds from the oils or their hydrolysis products [100]. The ethanol extract of $C$. annuum has been shown to have a larvicidal activity against Anopheles stephensi and Culex quinquefasciatus. The treated larvae revealed curling up agitation and active body movements that were the characteristics of neurotoxicity.

\subsection{Biological Activity}

\subsubsection{Antioxidant Properties}

C. annuum, C. chinense, and C. frutescens contain an extensive range of secondary metabolites with renowned antioxidant properties [101]—for example, carotenoids [102]; capsaicinoids [17,103,104]; and phenolic compounds, predominantly flavonoids, quercetin, and luteolin [74,105-107]. Rosa et al. [103] showed that capsiate, dihydrocapsiate, and their analogues possess a highly significant antioxidant activity. The ingestion of $C$. annuum for 4 weeks was discovered to elevate the resistance of serum lipoproteins to oxidation in adult men and women, the antioxidant property of capsaicinoids giving additional advantage in the management of cardiovascular diseases [108]. The carotenoids extracted from dried C. annuum were also examined for their antioxidant activities [109].

\subsubsection{Anti-Inflammatory Properties}

C. annuum displayed hypocholesterolemic properties in animal assays $[110,111]$. A recent experiment established that hyperlipidemia, inflammation, and oxidative stress are closely associated with the pathogenesis of atherosclerosis and, subsequently, with the augmented risk of cardiovascular diseases $[112,113]$. Hence, an agent that has antioxidant and anti-inflammatory activities was beneficial in the deterrence of these pathologies. Chili pepper C. baccatum var. pendulum is broadly ingested in Brazil, and a few studies discovered in the literature place emphasis on its carotenoid and capsaicinoid constituents and the antioxidant activity of its crude juice [107,114,115]. Topical capsaicinoid-containing patch applications or local capsaicin injections $(2,10,20 \mu \mathrm{g} / \mathrm{paw})$ alone did not have an effect on edema volume and weight. However, the mixture of diclofenac with topical capsaicinoid-containing patches considerably upsurged the efficiency of diclofenac on inflammation [116]. The anti-inflammatory effects of the ethyl acetate extract of $C$. frutescens (CFE) were studied on rat hind paw inflammation induced by subplantar injections of fresh egg albumin $(0.5 \mathrm{~mL} / \mathrm{kg})$. The ethyl acetate extract of $C$. frutescens generated anti-inflammatory effects that were similar to diclofenac [117]. In addition, C. annuum showed an anti-inflammatory activity by inhibiting the Soyal lipoxygenase (LOX) enzyme. The outcome displayed a greater \% of LOX inhibition by green Capsicum ( $46.12 \%)$, followed by yellow $(44.09 \%)$ and red Capsicum (32.18\%) [118]. Carotenoid extracts from dried C. annuum displayed substantial peripheral analgesic activities at 5,20, and $80 \mathrm{mg} / \mathrm{kg}$ and induced central analgesia at $80 \mathrm{mg} / \mathrm{kg}$. The guajillo pepper carotenoid extracts also revealed anti-inflammatory activity; they considerably thwarted edema 
formation at a dose of $5 \mathrm{mg} / \mathrm{kg}$, which is comparable to the control treatment. A comparable action was achieved with indomethacin compared to the control treatment [72].

\subsubsection{Cardiovascular Effects}

C. annuum contains an anticoagulant that helps avert the clotting of the blood, resulting in strokes [4]. Natural $\alpha$-amylase and $\alpha$-glucosidase inhibitors from food-grade plants propose interesting approaches for the management of type- 2 diabetes. The concomitantly related macrovascular complication of hypertension can be achieved by comparable extracts via the inhibition of the angiotensin I-converting enzyme (ACE). Nine types of pepper (C. annuиm) were examined for their potent inhibitory activity against $\alpha$-amylase, $\alpha$-glucosidase, and ACE inhibitors. Numerous pepper extracts revealed a raised $\alpha$-glucosidase inhibitory activity, not connected to the total phenolic content and the antiradical activity. Choice extracts, for instance, green pepper and long hot pepper, displayed a low or no inhibitory effect against $\alpha$-amylase. Numerous aqueous extracts of red pepper displayed the uppermost ACE inhibitory activity [119]. An in vitro thrombolytic model was employed to observe the clot lysis property of $C$. frutescens. However, an in vitro thrombolytic model, $C$. frutescens, and a mixture of honey and C. frutescens revealed $57.40 \%$ and $44.54 \%$ clot lysis effects, respectively [120]. A recent study analyzed pepper oleoresin effects on gerbil males, and the researchers noticed that oleoresin reduced the triglycerides and cholesterol levels in the blood by $66 \%$ and $70 \%$, respectively. It was hypothesized that this effect was due to a decreased intestinal absorption of exogenous cholesterol as a result of the increased biliary excretion of endogenous cholesterol after feeding some rabbits with a diet rich in cholesterol (1\%) and chili pepper (1\%) for 12 weeks [121]. As a result, the hematic concentrations of cholesterol, low-density lipoproteins (LDL) and very low-density lipoproteins (VLDL) were lower, and the risks of atheroma formation were reduced. It was also known that chili seeds contain lecithin, which is a natural emulsifier of fats that keeps the cholesterol in suspension in the blood, preventing it from settling on the arteries. Several studies have indicated that capsaicinoids inhibit platelet aggregation. Marbut et al. [46] confirmed this characteristic of capsaicin [122]. The ethanolic extracts of $C$. annum efficiently regulate arthritis growth. The arthritis scores of adjuvant induced arthritis (AIA) were considerably reduced with the leaf extracts of $C$. annum [123]. The nanovesicle formulation displayed a healthier acceptability and recognition in human and animal models [124]. A paste of leaves is used in the management of arthritis [125]. Moreover, recent research documented the effect of capsaicinoid on the plasma fat and aorta functionality, including fecal sterol excretion; biomarkers of cholesterol absorption; atherosclerotic plaque development; and the gene expression of major enzymes, transporters, and receptors involved in cholesterol metabolism in hamsters [126]. Srinivasan et al. [127] revealed the efficacy of capsaicinoids in decreasing the plasma total cholesterol, enhancing the lipoprotein profile, and reducing the aortic plaque in high-cholesterol-fed conditions. They revealed that capsaicinoids lowered the plasma campesterol/cholesterol ratio, indicating a decrease in cholesterol absorption. Additionally, capsaicin caused apnea, decreased heart rate, and produced hypotension when injected intravenously or into the carotid sinus [44]. The cardiovascular system comprises capsaicin-sensitive sensory nerves which participate in the control of the cardiovascular role via the activation of transient potential vanilloid 1 (TRPV) and substance $P$ and the release of calcitonin gene-related peptide (CGRP). Several studies have indicated that capsaicinoids have therapeutic roles in curing disorders of the cardiovascular system [128-130]. Capsaicin also prevented platelet aggregation and the activity of clotting factors VIII and IX, a property which decreases the occurrence of cardiovascular diseases [128,129].

\subsubsection{Anti-Obesity Effect}

The anti-obesity property of the aqueous extracts of seven edible green peppers belonging to C. annuum L. of the Solanacese family-Putgochu (Pca), Oyee gochu (Oca), Kwari putgochu (Kca), Green pepper (Gca), Yellow paprika (Yca), Red paprika (Rca), and Cheongyang gochu (Cca)-was investigated via the assessment of the lipoprotein lipase (LPL) mRNA expression level in 3T3-L1 
cells (mouse pre-adipocytes) [119]. After capsaicin removal by chloroform defatting, the freeze-dried powder of Cca was administered to 3T3-L1 cells, and the anti-obesity effects were observed by assessing the LPL mRNA level via the RT-PCR protocol. Of the seven diverse $C$. annuum varieties, a substantial reduction in the LPL mRNA expression level of 50.9\% in the Cca treatment was observed compared to the negative group [130]. The chronic administration of capsiate, a non-pungent capsaicin-related compound derived from a highly concentrated $\mathrm{CH} 19$ sweet pepper fruit, was reported to enhance the loss of fat in both humans and rodents without any toxic effect. This anti-obesity activity was induced by accelerating the oxidation of basal fatty acids in the mitochondria [131,132]. In particular, the oral administration of capsiate has been shown to stimulate the transient potential vanilloid 1 (TRPV1) receptor, which in turn raises the lipolysis of fat tissues through the sympathetic nervous system and thermogenesis [132]. Moreover, Snitker et al. [55] stated that chronic capsiate administration increases $\mathrm{O}_{2}$ consumption, enhancing energy expenditure and fat oxidation and reducing abdominal adiposity in experimental animals and in humans, especially those with a high BMI. Thus, capsiate could represent a promising approach in antiobesity programs, especially for individuals during a time of limited energy intake [133]. Ohyama et al. [134] revealed the synergistic antiobesity effect of capsiate, dihydrocapsiate, and nordihydrocapsiate, and cold temperature combination by stimulating beige adipocyte biogenesis and energy expenditure.

\subsubsection{Immunosuppressant and Memory Enhancing Activity}

The direct administration of Capsicum extract and capsaicin caused the downregulation of interleukin (IL)-2, interferon (IFN)-gamma, and IL-4 and IL-5 production. Furthermore, a flow cytometric analysis showed a reduced population of CD3 (+) cells and an increase in CD19 (+) cells. The immunological effects of red pepper (C. annuum L.) extracts and its chief pungent capsaicin was evaluated on T helper 1 (Th1) and 2 (Th2) cytokine generation in cultured murine Peyer's patch (PP) cells in vitro and ex vivo. In ex vivo research using PP cells detached from mice after oral treatment with Capsicum extract ( $10 \mathrm{mg} / \mathrm{kg} /$ day) for 4 successive days, IL-2, IFN-gamma, and IL-5 were found to upsurge in reaction to concanavalin A (Con A). Treatment with $3 \mathrm{mg} / \mathrm{kg} / \mathrm{day}$ of capsaicin also improved the IL-2, INF-gamma, and IL-4 generation in reaction to Con A activation but did not sway the production of IL-5 [135]. Green chili is a favorable memory enhancer, and the fundamental mode of action of green chili seems reliant on (i) the enhancement of memory in exteroceptive models, (ii) the retrieval of memory shortfalls, (iii) the improved scavenging of radicals, and (iv) the inhibition of acetylcholinesterase.

\subsubsection{Antiangiogenic and Anti-Neoplastic Effects}

Angiogenesis refers to the growth of new blood vessels from pre-existing vasculature. It is a complex multistep process involving endothelial cell activation, cell proliferation, invasion, chemotactic migration, and differentiation into new blood vessels [136]. The acquisition of an angiogenic phenotype is considered to be a vital step in tumor progression $[137,138]$. Several congruent studies indicate that the transition from an in situ carcinoma to invasive cancer (for solid tumors) must be accompanied by neovascularization. Therefore, the suppression of angiogenesis is a highly effective strategy for the treatment of multiple cancers [139-141], and one for which capsaicinoids may have relevant therapeutic potential, as they demonstrate significant anti-angiogenic activity in both cell culture and mice models. The effects of capsaicin on angiogenesis were investigated using multiple models [142]. Capsaicin has been proven to inhibit vascular endothelial growth factor (VEGF)-induced angiogenesis in ex vivo rat aortic rings models, Matrigel model systems, in vivo Matrigel plug experiments, and chicken chorioallantoic membrane (CAM) models [142]. Capsaicin robustly inhibited VEGF-induced endothelial cell proliferation and invasion [142]. Similarly, the non-pungent capsinoids, capsiate and dihydrocapsiate, inhibited VEGF-induced angiogenesis in both cell culture and mouse models [143]. Capsiate and dihydrocapsiate inhibited the VEGF-induced endothelial permeability and formation of cell-cell junctions by the direct inhibition of Src kinase activity and the phosphorylation of its 
downstream substrates (e.g., vascular endothelial cadherin and $\mathrm{p} 125^{\mathrm{FAK}}$ ). The anti-angiogenic activity of capsiate and dihydrocapsiate was found to be independent of the TRPV1 receptor [143]. The antiangiogenic activities of capsiate and dihydrocapsiate were compared to those shown by capsaicin. These non-pungent capsaicinoids (capsiate and its associated compounds) may be more important than capsaicin in the treatment of cancer; however, there are no records of other natural and synthetic capsaicin analogs having antiangiogenic action [144].

There are contradictory reports on the anti-cancer activity of capsaicinoids. The anticancer property of capsaicin was documented in diverse kinds of cancer cell; capsaicin blocked breast cancer cell migration and killed prostate cancer cells. Dihydrocapsaicin induced autophagy in HCT116 human colon cancer cells. Capsaicin also inhibited the growth of leukemic cells. The investigation of the mechanism of action of capsaicin has shown that it induced cell cycle arrest and apoptosis and inhibited cellular metabolism. Capsaicin selectively thwarted the growth and induced the apoptosis of cancerous cell lines. However, the biochemical constituents of capsaicin (such as the reactive phenoxy radicals) might assault the DNA and activate mutagenicity and cancerous transformation [145]. Many studies have shown that low doses of capsaicin inhibit the development of many forms of human cancers. Capsaicin has a deep anticarcinomic effect on prostate cancer cells, causing the cell death of both androgen receptor-positive and negative prostate cancer cell lines linked to the elevation of the antibodies p53, p21, and Bax [146]. Besides this, capsaicin efficiently inhibited tumor growth and induced apoptosis with no toxic effects [147]. All capsaicin-like compounds (natural capsaicinoids or synthetic capsaicin mimetics) have displayed growth-inhibitory effects against several cell lines [148]. For instance, capsanthin, capsanthin $3^{\prime}$-ester, capsanthindiester, capsorubin, capsorubindiester, capsanthin 3,6-epoxide, cucurbitaxanthin A-3'ester, and $\beta$-carotene isolated from the fruits of $C$. annuum validated potent in vitro anti-tumor-promoting activity, with inhibitory effects on the Epstein-Barr virus early antigen activation induced by the tumor promoter 12-O-tetradecanoyl-phorbol-13-acetate [149]. After the incubation of adenocarcinoma cell lines with capsaicin for $24 \mathrm{~h}$, the cell viability was reduced considerably in a concentration-dependent manner, and the apoptotic bodies significantly increased [150]. Additionally, nordihydrocapsiate exhibited a potent chemopreventive effect in an in vivo two-stage model of mouse skin carcinogenesis. These results may indicate that nordihydrocapsiate can provide defense against skin cancer and shows a better proapoptotic activity than capsaicin in Jurkat cells [144]. These capsiates act by inhibiting the transcription factor nuclear factor $\kappa \mathrm{B}$, increasing reactive oxygen species, and causing the loss of mitochondrial membrane potential [151]. N-acylvanillamides (N-AVAMs), synthetic non-pungent capsaicin analogs, are among the most common compounds studied for their anticancer and analgesic activity. Several studies have revealed their anticancer activity against different human cancer cell lines $[152,153]$. Recently, the growth-inhibitory effect of unsaturated N-AVAMs (UN-AVAMs) has been investigated. For instance, Tuoya et al. [154] reported that dohevanil, a UN-AVAM, induced higher apoptosis than capsaicin against MCF-7 human breast cancer cells in vitro. Moreover, several UN-AVAM compounds showing different affinities for human TRPV1 receptor have been synthesized by Appendino et al. [155]. The combinatorial anticancer effect of capsaicin analogs with traditional chemotherapy or radiation is an interesting field of study and research. As well, the production of non-pungent second-generation capsaicin mimetics with antiangiogenic and anticancer activities will open the way for new therapeutic interventions for human cancers [144].

\subsubsection{Anti-Invasive and Anti-Migratory Activities of Capsaicinoids}

A critical step in the metastatic process is the migration and invasion of cancer cells into the surrounding blood vessels, lymph nodes, and stroma [156]. There are contradictory studies about the effect of capsaicin on tumor cell migration and invasion. Additionally, Yang et al. [157] revealed that capsaicin induced human colon carcinoma cell invasion through signal transducer and activator of transcription 3 (STAT-3) and Akt/mTOR-dependent pathways. Other reports have documented that capsaicin exhibits anti-invasive and anti-migratory activities against thyroid cancer, breast 
cancer, bladder cancer, small cell lung cancer (SCLC), cholangiocarcinoma, and melanoma [158,159]. Capsaicin's anti-migratory and anti-invasive activity in thyroid cancer has been shown to be induced by a TRPV1-dependent mechanism [158]. Capsaicin has been found to enhance the invasion of TRPV1-null 5637 human bladder cancer cells [160]. Capsaicin's pro-invasive activity correlates with increased granzyme A (GZMA) and insulin growth factor production (IGF-1), and matrix metalloproteinase-9 (MMP-9) activation in TRPV-null cells. Capsaicin utilizes several signaling pathways to control cancer cell migration and invasion, including the MMP signaling pathway; adenosine monophosphate (AMP) activated protein kinase (AMPK); epithelial-mesenchymal transition (EMT) activation; VEGF; intracellular calcium elevation; tumor-associated NADH oxidase (tNOX); MMPs; Akt; Wnt-Hedgehog regulation; and p38 MAP kinase, extracellular signal-regulated kinase (ERK), epidermal growth factor receptor (EGFR), AP-1, NF-kB, and Rac1 inhibition [161,162]. The capsaicin analogs, arvanil and olvanil, demonstrated higher anti-invasive activity against a panel of human SCLC cell lines relative to capsaicin, and this activity was independent on TRPV1 and regulated by the AMPK pathway activation [159]. The anti-invasive activity of capsazepine, another capsaicin analog, against human prostate cancer cells was investigated by Lee et al. [163]. They found that capsazepine strongly inhibited DU145 human prostate cancer cell invasion by inhibiting the Janus kinase (JAK)/STAT3 pathway.

\subsubsection{Anti-Metastatic Activity of Capsaicinoids}

Several studies have investigated the sensory effects of capsaicin on tumor metastasis [164]. For example, O'Neill et al. [165] as well as Erin et al. [166] revealed that high concentrations of capsaicin led to sensory neuron deactivation. Yang et al. [157] also demonstrated capsaicin's effect on the metastasis of CT26 murine colorectal carcinoma cells. Venier et al. [167] examined capsaicin's anti-metastatic activity in a transgenic adenocarcinoma of the mouse prostate (TRAMP) model of prostate cancer. They revealed that capsaicin administration greatly decreased the metastatic burden in the model TRAMP mice. This research indicates that capsaicin may have a strong anti-metastatic activity [167].

\subsubsection{Analgesic and Antiplatelet Effects}

The analgesic effects of capsaicin are significantly improved through inflammation, supporting the fact that the activation of vanilloid receptor type 1 could possibly constitute an appropriate approach to thwart inflammatory hyperalgesia [168]. The neuropeptide substance $P$ has been involved in the pathogenicity of inflammation and pain in arthritis. A significant pain reduction of $57 \%$ and $33 \%$ was documented by a $0.025 \%$ capsaicin cream in treating osteoarthritis and rheumatoid arthritis in patients, respectively [169]. It was indicated that the management of individuals with headaches with capsaicin may make inactive sensory neurons by decreasing the nerve terminals of the substance $\mathrm{P}$, which indicates that intranasal capsaicin offers a different management option for the handling of this disease [170]. The analgesic effect of SDZ 249-665, a capsaicin analogue, has been reported in a nociceptive pain mouse model showing an anti-hyperalgesic effect in rat and guinea pig inflammatory pain models. It was more effective than capsaicin by 45 times when administered orally and 3 times subcutaneously. The absence of the excitatory and pungent effects associated with capsaicin constitutes a significant possible benefit of SDZ 249-665 [171]. The analgesic activity of UN-AVAMs compounds has been completely restored by introducing long-chain unsaturated fatty acids. Structural activity experiments tested the unsaturation degree in these side chains, and the side chain length generates analogs of capsaicin with an enhanced analgesic activity and binding profile to TRPV1 [153]. Capsaicin was discovered as a strong inhibitor of platelet aggregation and release reaction. It reduced the hemolysis of red blood cells (RBCs) caused by hydrogen peroxide. Capsaicin has a membrane steadying effect by the interference of the stimulation of the phospholipase A2 [172]. 


\subsubsection{Diabetic Neuropathy and Gastroprotective Effects}

The anti-diabetic effect of $C$. annuum has been demonstrated and takes place through various mechanisms, such as the inhibition of $\alpha$-glucosidase, $\alpha$-amylase, and antioxidant activities; the insulin mimetic, weight control, and hypolipidemic effects of this plant; and the activation of TRPV1, which leads to improved insulin resistance, the suppression of inflammation, and the control of glucose homeostasis. Moreover, $C$. annuum can act by enhancing the insulin sensitivity in peripheral tissues, stimulating the secretion of glucagon-like peptide-1 (GLP1), improving glucose tolerance, protecting $\beta$ cells from apoptosis, and decreasing the level of fasting glucose/insulin and adipocytokine gene expression [173]. Sanati et al. [174] reported that short-term red pepper treatment decreased the level of serum glucose in diabetic rats, whereas a long-term treatment decreased the levels of triglycerides only. Moreover, Baek et al. [119] studied the inhibitory property of $C$. annuum against $\alpha$-amylase, $\alpha$-glucosidase, and angiotensin I-converting enzyme (ACE) inhibitors. Clinical trials carried out in individuals with diabetic neuropathy established a 50\% enhancement in pain status with the usage of capsaicin for 22 weeks. It acts by exciting nociceptive C-afferent neurons, triggering the release of the substance $\mathrm{P}$, which is important in order for the transmission of nociception to happen in the nervous system. The repeated application of capsaicin reduces substance $P$, resulting in pain sensation inhibition [80]. The crude extract of the fruit was discovered to thwart glucose absorption, which is partly accountable for reducing blood glucose [175]. The regular ingesting of chili may mitigate postprandial hyperinsulinemia [176]. Capsaicin reduced the gastric basal output and improved the non-parietal constituent of gastric secretory responses, gastric draining, and the release of glucagon. Capsaicin stopped indomethacin- and ethanol-induced gastric mucosal injury; meanwhile, capsaicin itself improved the gastric transmucosal potential difference. It can be summarized that capsaicin represents a new orally applicable gastro-protective agent in individuals with diverse chemical and Helicobacter pylori-induced mucosal damage and in numerous ailments necessitating treatment with non-steroidal anti-inflammatory drugs [177].

\subsubsection{Antiulcer and Respiratory Properties}

C. frutescens was used as a curative against severe ulcers induced by aspirin at dosages of 300 and $600 \mathrm{mg} / \mathrm{kg}$, and the outcome showed that the administration of the extract decreases the amount of gastric juice, reduced the length of gastric ulcers, and improved the histology alterations [178]. Red pepper has been employed for a long time as a digestive. Traditionally, conventional ulcer medicines avoid pepper, whereas herbalists recommended it. A study indicated that capsaicin inhibits in the vitro development of Helicobacter pylori at $10 \mu \mathrm{g} / \mathrm{mL}$, negatively affecting the genesis of peptic and duodenal ulcers. In addition, capsaicin stimulates the formation of prostaglandins [179] by nerves sensitive to capsaicin. This research showed that the intake of 0.1 and $0.5 \mathrm{mg} / \mathrm{kg}$ of capsaicin after administration with indomethacin (NSAIDs) reduces the possible gastric lesions consequential to the use of NSAID agents. These lesions are normally caused by the NSAID-mediated reduction in prostaglandin production by the gastric mucosa. In fact, prostaglandins prevent gastric lesions because they act as stimulants of the production of mucus and bicarbonate [122]. Cough sensitivity to capsaicin is utilized as a device in biomedical studies. The cough sensitivity to capsaicin is used in the clinical evaluation of cough suppressants, such as benzonatate and guaifenesin [180]. In biomedical research, capsaicin weakens the nasal mucosa and lessens the allergic signs of nasal reaction or pain caused by additional agents [181]. Capsaicin offers a defensive approach by bolstering the lung defense system. Capsaicin has realized extensive usage in biomedical practice, since it causes coughing in a concentration-dependent and replicate manner [182]. 


\subsubsection{Dermatological Conditions, Pruritus, Psoriasis, and Rhinitis}

Capsaicin, a recognized inhibitor of cutaneous vasodilatation, offers aid in reasonable and adverse psoriasis. A considerably enhanced decrease was perceived on parts administered with capsaicin comparable to the sides administered with buffer. The side effects were observed closely by the individuals during the early use of the examined medicine; however, they lessened or disappeared upon sustained usage [183]. Topical $0.075 \%$ capsaicin cream was positively utilized in the management of acute lipodermatosclerosis in pregnant woman [184]. Capsaicin principally influenced the slow steady curative of the skin lesions. Topical capsaicin is revealed to efficiently cure pruritus [185]. It was discovered that individuals with very itchy platelet-rich plasma (PRP) administered with capsaicin were seemingly discharged [186]. Capsaicin is also utilized in managing prurigo nodularis [187]. Topical capsaicin is revealed to efficiently cure pruritus, which is relevant to psoriasis [185,188], pityriasis rubra pilaris [186], psoralen-ultraviolet-light (PUVA) treatment [189], prurigo nodularis [190], and pruritus [187]. However, large, high-grade clinical trials are deficient. An evidence-based review of botanicals for dermatologic situations showed the data from two 6-week clinical trials $(n=241)$ on the usage of capsaicin cream on psoriasis. Capsaicin was better than the placebo for the respite of the signs of scaling, thickness, erythema, and pruritus. Burning at the application site was the most frequently documented severe effect [191]. A Cochrane review of the effectiveness of inhaled capsaicin in allergic rhinitis was discovered to lack proof to aid clinical use [188-190]. The biological activity is shown in Figure 2 and Table 6.

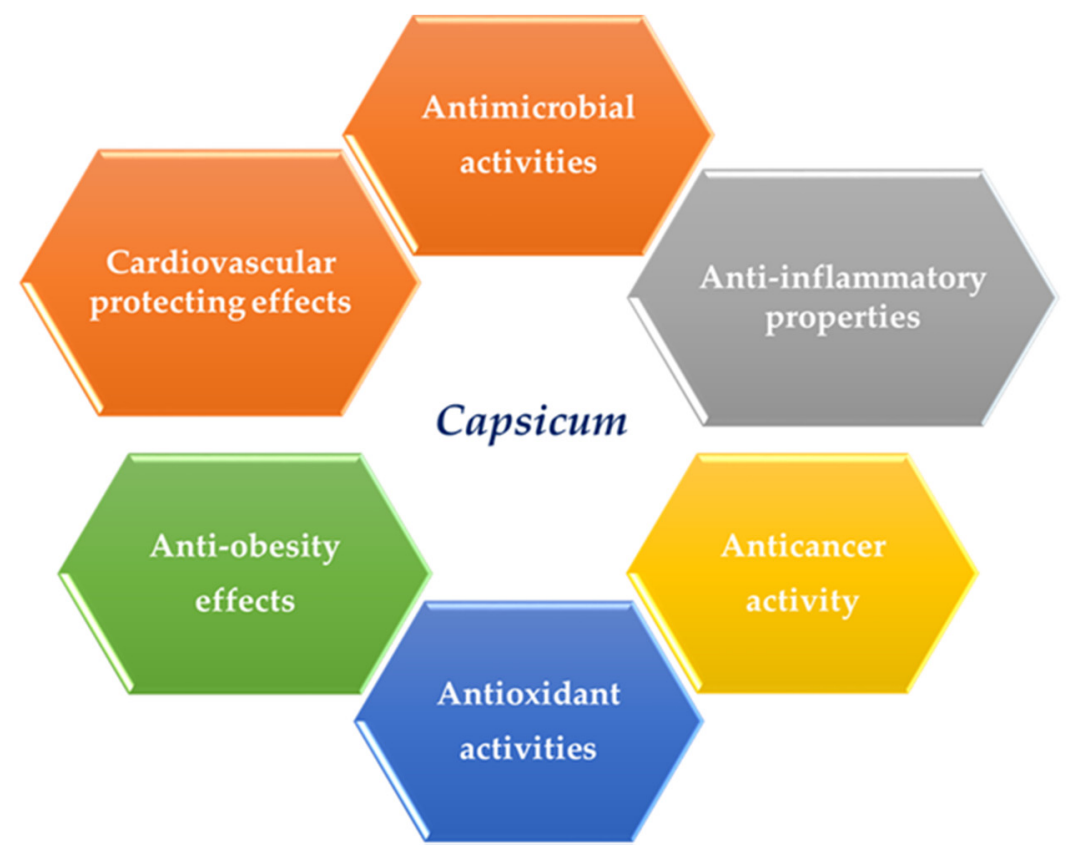

Figure 2. Summary of the biological activity of Capsicum. 
Table 6. The biological activities of Capsicum.

\begin{tabular}{|c|c|c|c|c|}
\hline Activities & Models & Extract & Bioactive Compound Mechanism of Action & References \\
\hline \multirow{4}{*}{ Antimicrobial effects } & $\begin{array}{l}\text { Micrococcus sp }(20 \mathrm{~mm}), \text { Bacillus }(10 \mathrm{~mm}), \text { E. Coli }(17 \\
\mathrm{mm}), \text { Pseudomonas sp }(16 \mathrm{~mm}) \text { and Citrobacter } s p(15 \\
\mathrm{mm})\end{array}$ & $\begin{array}{l}\text { The butanol extract of Capsicum } \\
\text { annuum fruit }\end{array}$ & Capsaicin. & [88] \\
\hline & Salmonella typhimurium and Pseudomonas aeruginosa & $\begin{array}{l}\text { The ethanol extract }(100 \mathrm{mg} / \mathrm{mL}) \\
\text { of Capsicum annuиm. }\end{array}$ & Capsaicin. & [89] \\
\hline & $\begin{array}{l}\text { (Staphylococcus aureus UFPEDA02, Enterococcus faecalis } \\
\text { ATCC6057, Bacillus subtilis UFPEDA 86), and Gram } \\
\text { negative (Escherichia coli ATCC25922, Klebsiella } \\
\text { pneumonia ATCC29665, Pseudomonas aeruginosa } \\
\text { UFPEDA416) bacteria and one yeast strain (Candida } \\
\text { albicans UFPEDA 1007) }\end{array}$ & C. frutescens extract. & $\begin{array}{l}\text { CAY-1, a novel saponin obtained from } C \text {. } \\
\text { frutescens, rupturing the membrane integrity of } \\
\text { fungal cells. }\end{array}$ & {$[88,91]$} \\
\hline & $\begin{array}{l}\text { Saccharomyces cerevisiae, Candida albicans, Candida } \\
\text { parapsilosis, Candida tropicalis, Pichia membranifaciens, } \\
\text { Kluyveromyces marxiannus and Candida guilliermondiiA. } \\
\text { flavusA. niger }\end{array}$ & Capsicum frutescens extracts. & Peptides obtained from chili pepper seeds. & [94] [93] \\
\hline Antiviral & Guinea pigs against cutaneous herpes simplex virus & Capsicum extract. & $\begin{array}{l}\text { Capsaicin, disrupting standard virus-neuron } \\
\text { connections. }\end{array}$ & [192] \\
\hline \multirow[t]{2}{*}{$\begin{array}{c}\text { Insecticidal, } \\
\text { anthelmintic and } \\
\text { Larvicidal effects }\end{array}$} & A. aegypti mosquitoes & Capsicum frutescens extracts. & Extremely repellent extracts. & [115] \\
\hline & Cercaria of Schistosoma mansoni & Capsicum annuum leaves extracts. & $\begin{array}{l}\text { Water-soluble unsaturated compounds from the } \\
\text { oils or their hydrolysis products. }\end{array}$ & [100] \\
\hline $\begin{array}{l}\text { Antioxidant } \\
\text { properties }\end{array}$ & Adult men and women & Capsicum annuum. & $\begin{array}{l}\text { Antioxidant properties of capsaicinoids gave } \\
\text { additional advantage in the management of } \\
\text { cardiovascular diseases. }\end{array}$ & [108] \\
\hline $\begin{array}{l}\text { Anti-inflammatory } \\
\text { properties }\end{array}$ & $\begin{array}{l}\text { Rat hind paw inflammation induced by subplantar } \\
\text { injections of fresh egg albumin }(0.5 \mathrm{~mL} / \mathrm{kg})\end{array}$ & Ethyl acetate $C$. frutescens extract & Carotenoids. & [117] \\
\hline Cardiovascular effects & Anesthetized dogs iv injections & Capsaicin $(10-300 \mu \mathrm{g} / \mathrm{kg})$. & $\begin{array}{l}\text { Temporary increase in the mean systemic blood } \\
\text { pressure trailed by a continued fall. }\end{array}$ & [193] \\
\hline \multirow[b]{2}{*}{$\begin{array}{l}\text { Antithrombotic and } \\
\text { Vasodilatory } \\
\text { Properties }\end{array}$} & Gerbil males & Pepper oleoresin. & $\begin{array}{l}\text { Decreasing intestinal absorption of exogenous } \\
\text { cholesterol as a result of the increased biliary } \\
\text { excretion of endogenous cholesterol. }\end{array}$ & [121] \\
\hline & $\begin{array}{l}\text { Feed rabbits for } 12 \text { weeks with a diet rich in } \\
\text { cholesterol }(1 \%) \text { and chili pepper }(1 \%)\end{array}$ & Chili pepper (1\%). & $\begin{array}{l}\text { Discovered the anti-atherosclerotic effects of } \\
\text { pepper. At the end of } 12 \text { weeks, a reduced } \\
\text { activity of cholesterol ester transfer protein } \\
\text { (CETP) was witnessed, in contrast to the control } \\
\text { group (rabbits feeding without pepper). }\end{array}$ & [194] \\
\hline
\end{tabular}




\section{Dosing}

For external uses, capsaicin and Capsicum creams are accessible in numerous ways, from capsaicin $0.025 \%$ to $0.075 \%$, and are applied up to 3 to 5 times daily. Capsicum plasters comprising powdered Capsicum $345.8 \mathrm{mg}$ and Capsicum $34.58 \mathrm{mg}$ tincture per sheet $(12.2 \times 16.4 \mathrm{~cm})$ have been assessed for postoperative pain and nausea [195]. A high-concentration dermal patch ( $8 \% \mathrm{w} / \mathrm{w}$ capsaicin) has been utilized in HIV-linked neuropathy [196] and intractable pain [197]. Low-strength $(0.006 \%)$ capsaicin ointment was utilized in the atrial of itching in pruritus ani, with higher strengths leading to anal burning [187].

\section{Pregnancy/Lactation}

Studies in animals have displayed both positive and negative effects. Capsaicin crosses the placenta and was revealed to reduce substance $P$ in the fetus with a neurotoxic effect. The growth rates of rat pups were lesser, and an abnormal testicular descent was observed in pups born to capsaicin-fed rats. However, no differences in rat pup malformations, epididymal or testicular weight, or plasma progesterone were established in other studies [198].

\section{Toxicity of Pepper}

Though most studies reveal that pepper and its bioactive compounds are safe, studies have specified its linked to cancer risks. Hwang et al. [199] stated that capsaicin might be associated with skin cancer. High gallbladder cancer (GBC) occurrence rates discovered were associated with high red chili pepper ingestion [200,201]. Szallasi et al. [202] reviewed the mutagenic effects of capsaicin on bacteria and mammals, and discovered contradictory outcomes. Although they resolved that capsaicin is not toxic (not mutagenic or weak mutagenic), the outcomes of tests displayed that ingestion might have carcinogenic or co-carcinogenic effects [202]. Within the body system, this may result in gastrointestinal cramping, discomfort, and diarrhea. Topically, this might trigger painful irritation of the mucous membrane [203]. The oral $\mathrm{LD}_{50}$ values for capsaicin are $161.2 \mathrm{mg} / \mathrm{kg}$ (rats) and $118.8 \mathrm{mg} / \mathrm{kg}$ (mice), with the hemorrhage of the gastric fundus detected in some of the animals that died. Although capsaicin is thought as safe and efficient as an external analgesic counterirritant, high doses administered over a protracted period of time can produce chronic gastritis, renal injury, hepatic damage, and neurotoxic effects [204,205]. Saito and Yamamoto [201] discovered that the acute oral $\mathrm{LD}_{50}$ values of capsaicin were estimated to be 97.4 and $118.8 \mathrm{mg} / \mathrm{kg}$ in female and male mice, respectively, and 148.1 and $161.2 \mathrm{mg} / \mathrm{kg}$ in female and male rats, respectively. The animals either died within $26 \mathrm{~min}$ of dosing, or revealed no further signs $24 \mathrm{~h}$ after dosing [206]. Acute myocardial infarction was described in a 40-year-old man admitted to a emergency division with complains of chest discomfort and dyspnea after exposure to pepper gas that spurted into the surroundings during a social event [184]. C. annuum must not be utilized during pregnancy and lactation in individuals with hypersensitivity and in children. The plant must not be employed on open wounds or abrasions, or near the eyes [207]. It also reduced the actions of $\alpha$-adrenergic blockers, clonidine, and methyldopa [98]. Epidemiological and case-control studies have revealed a 2- to 3-fold upsurge risk of cancers, as well as oral, pharyngeal, and esophageal studies, and a movement toward an augmented risk of gall bladder, stomach, and colon cancers with chili consumption. There are varied results for capsaicin as a carcinogen, cocarcinogen, and anticarcinogen [198]. The preliminary interaction of capsaicin with the skin offers a fierce irritation with successive desensitization. In protracted exposure and in adverse cases, tenacious dermatitis with adverse effects may occur [208]. The interaction of the eyeball with Capsicum produces redness, inflammation, and tearing. More adverse indications comprise tenacious pain and foreign body sensation [209]. Reduced tear production and damaged corneal reflex lacrimation have been documented [210]. The toxic effects of Capsicum on the eyeball were documented by numerous researchers [208,211]. Contact may happen via breathing, producing an immediate redness of the mucous membranes [212]. The other signs documented comprise adverse 
coughing, mucus secretion, difficulty in breathing, and chest tightness [213]. Internally, Capsicum may produce gastrointestinal constrain, discomfort, and diarrhea. It produces sore irritation of the skin. A high dosage of capsaicin over a protracted time can produce renal injury, hepatic impairment, and neurotoxic effects [204]. Some studies have described systemic signs, comprising hyperventilation and lung edema. The severe upsurge in blood pressure might produce pain and amplify strokes [213]. A summary of the toxic effects of Capsicum is shown in Table 7.

Table 7. Toxic effects of Capsicum.

\begin{tabular}{llll}
\hline \multicolumn{1}{c}{ Toxic Activities } & Bioactive Compound/Type of Extract & $\begin{array}{l}\text { Mechanism of Action of } \\
\text { Toxicity }\end{array}$ & Ref. \\
\hline $\begin{array}{l}\text { Hemorrhage of the } \\
\text { gastric fundus }\end{array}$ & $\begin{array}{l}\text { Capsaicin } \\
161.2 \mathrm{mg} / \mathrm{kg} \text { (rats) and } 118.8 \mathrm{mg} / \mathrm{kg} \text { (mice). }\end{array}$ & $\begin{array}{l}\text { Triggers painful } \\
\text { irritation of the mucous } \\
\text { membrane. }\end{array}$ & $\begin{array}{c}\text { [204, } \\
\text { 205] }\end{array}$ \\
\hline Myocardial infarction & $\begin{array}{l}\text { 40-year-old man admitted to emergency } \\
\text { division with complains of chest } \\
\text { discomfort and dyspnea after exposure to } \\
\text { pepper gas. }\end{array}$ & $\begin{array}{l}\text { Irritation of the mucous } \\
\text { membrane. }\end{array}$ & [184] \\
\hline Tenacious dermatitis & Capsaicin & Irritation of the skin. & [208] \\
\hline
\end{tabular}

\section{Adverse Reactions}

Reactions to bananas, kiwi, chestnut, or avocado may dispose individuals to Capsicum (pepper) allergy [214]. Allergic reactions to paprika occur in patients with "mugwort-celeryspice" syndrome [215].

\section{Drug Interaction}

Interactions were documented with the concurrent treatment of $C$. annuum with aspirin and salicylic compounds [216].

\section{Pharmacokinetics of Capsicum and its Related Compound (Capsaicin)}

Chaiyata et al. [217] investigated the metabolic rate (MR) of $5 \mathrm{~g}$ of fresh chili pepper in Thai women. They revealed that the MR immediately increased after fresh chili pepper ingestion and lasted for up to $30 \mathrm{~min}$. Moreover, Weerapan Khovidhunkit [218] showed that the oral administration of $5 \mathrm{~g}$ gel capsules of Capsicum in humans maintained insulin levels, and that capsaicin can be first detected in the plasma at 10 min with a peak plasma concentration $\left(\mathrm{C}_{\max }\right), \mathrm{T}_{\max }, \mathrm{AUC}(0-\mathrm{t})$, and $\mathrm{T}_{1 / 2}$ of $2.47+/-0.13 \mathrm{ng} / \mathrm{mL}, 47.08+/-1.99 \mathrm{~min}, 103.6+/-11.3 \mathrm{ng} \times \mathrm{min} / \mathrm{mL}$, and $24.87+/-4.97 \mathrm{~min}$, respectively. Early studies have reported the liver metabolism of capsaicin [219]. Several research laboratories have examined the liver metabolism of capsaicinoids in vitro via liver microsomes [220]. The metabolism was quicker in the rat and human hepatic microsomes than the corresponding $9000 \mathrm{~g}$ supernatant. Chanda et al. [221] perceived that capsaicin was totally metabolized within $20 \mathrm{~min}$ in rat and human microsomes. The highest levels were detected in diverse tissues at several times.

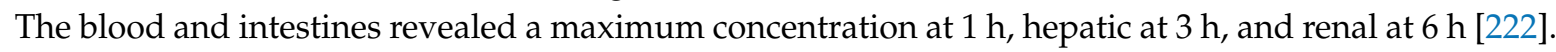
The absorption of orally administered capsaicin seems to be quick relative to the other two spice principles, as specified by its maximum concentration in the intestinal tissue at $1 \mathrm{~h}$ [222]. About 6.3 percent of the administered capsaicin was expelled as such in the feces over a period of 4 days, with the peak excretion happening on the first day of oral intake. Therefore, approximately 94 percent of orally administered capsaicin is digested. Only a small part of capsaicin was also expelled intact in urine $(0.095 \%)$ [223]. Kawada et al. [224] have documented from an in vivo study in rats that the gastrointestinal absorption of capsaicin is rapid, and about 85 percent of the dose was absorbed within $3 \mathrm{~h}$. Additionally, the absorbed capsaicin is willingly transported to the portal blood (about $85 \%$ ) and partially metabolized during absorption to 8-methyl nonanoic acid. The metabolism of capsaicin was discovered to be comparable in human, rat, and dog microsomes [225]. In the tissue 
distribution and excretion of orally administered piperine, a maximum of 10.8 percent of administered piperine was observed in these tissues by $6 \mathrm{~h}$ after administration [222]. The quantity of piperine in the serum was $6.07,9.75$, and $11.1 \mu \mathrm{g} / \mathrm{mL}$ at 1,3 , and $6 \mathrm{~h}$, respectively, which weakened significantly to $0.93 \mu \mathrm{g} / \mathrm{mL}$ at the end of $24 \mathrm{~h}$ and was nil in the blood after 4 days. Piperine was not noticeable in the urine at any time interval. Alternatively, 3.64 percent of the administered piperine was excreted as such in the feces over a period of 4 days, with the peak excretion occurring on the first day of oral intake. Therefore, the absorption of the administered piperine was about 96 percent [222]. Three key metabolites recognized for capsaicin were 16-hydroxycapsaicin, 17-hydroxycapsaicin, and 16 and 17dihydrocapsaicin. This was mostly removed by the kidneys, with a small amount defecated in the feces and urine $[99,226]$. Capsaicin is well absorbed from the topical application on the skin, when a $3 \%$ capsaicin solution applied topically was speedily absorbed and reached optimum concentration. The shelf-life of capsaicin was roughly $24 \mathrm{~h}$ [99].

\section{Future Directions}

A number of unpleasant side effects are associated with the pungent nature of capsaicin after oral administration which hinder its use as a possible therapeutic agent. Such adverse effects, including sweating, eye tearing, gastric pain, and ulcers, as well as its short half-life and low bioavailability, mostly promote patients to stop its use, making any clinical trials useless [203,209]. Several approaches were identified for enhancing capsaicin's bioavailability, including iontophoresis, hydrogel formations, and encapsulation in liposomes. Nanotechnology has recently been used to generate continuous release formulations of capsaicin $[227,228]$. For instance, some capsaicin formulations can induce a more persistent and sustained release of capsaicin to the site of the target organ. Tan et al. [229] revealed that most of the sustained-release topical capsaicin formulations exhibit greater skin permeability than capsaicin creams. Other capsaicin formulations exhibit a reservoir effect by reducing the capsaicin dose needed for treatment, thus resulting in less side effects, such as capsaicin formulations based on nanoparticles, leading to minimum discomfort in animal models. Capsaicin nanoparticles can also be used in combination therapy with other medications [230]. The discovery of second-generation capsaicin mimetics is another approach for resolving capsaicin side effects that would have a higher pharmacological activity than capsaicin [148]. Several natural capsaicinoids have been extracted from peppers and other natural sources. Likewise, synthetic capsaicin analogs were developed to manipulate the capsaicin pharmacophore. Long-acting analogs of capsaicin and capsaicin mimetics may form the basis of modern pharmacological treatments against a broad variety of human diseases, such as cancer, chronic pain, and atherosclerosis [230].

\section{Conclusions}

Pepper (Capsicum spp.) is among the oldest cultivated and most employed crops. Its usage started quite a long time ago and was considered to have its source in America. The genus Capsicum contains over two hundred species, with the fruits differing extensively in form, taste, and olfactory heat. Capsicum fruits are rich in capsaicinoids, carotenoids, flavonoids, vitamins, and minerals. The composition and quantity of these compounds vary according to the genotype and other factors. Capsaicin, the main active constituent isolated from Capsicum spp., is metabolized in the liver to three main metabolites-namely, 16-hydroxycapsaicin, 17-hydroxycapsaicin, and 16 and 17dihydrocapsaicin - that were mostly removed by the kidneys, with a small amount defecated in the feces and urine. Capsicum produces redness, inflammation, tearing, tenacious pain, abdominal and skin irritation, coughing, and foreign body sensation. Capsaicin and Capsicum creams have been used externally and are accessible in numerous ways, from capsaicin $0.025 \%$ to $0.075 \%$, and are applied up to 3 to 5 times daily. Capsicum plasters comprising powdered Capsicum $345.8 \mathrm{mg}$ and Capsicum $34.58 \mathrm{mg}$ tincture per sheet $(12.2 \times 16.4 \mathrm{~cm})$ have been assessed for postoperative pain and nausea. 
Author Contributions: G.E.-S.B., A.A., O.A.O., H.M.S., L.W., M.E., M.I., M.S., T.M., A.Z.-B., N.R.-P., A.M.B., K.I.K., P.J. and H.F.H. wrote the paper. G.E.-S.B., O.A.O., P.J. and A.M.B. revised the paper. All authors have read and agreed to the published version of the manuscript.

Funding: This research received no external funding.

Conflicts of Interest: The authors declare no conflict of interest.

\section{References}

1. Kraft, K.H.; Brown, C.H.; Nabhan, G.P.; Luedeling, E.; Ruiz, J.d.J.L.; D’Eeckenbrugge, G.C.; Hijmans, R.J.; Gepts, P. Multiple lines of evidence for the origin of domesticated chili pepper, Capsicum annuum, in Mexico. Proc. Natl. Acad. Sci. USA 2014, 111, 6165-6170. [CrossRef] [PubMed]

2. Andrews, J. The Pepper Trail: History and Recipes from Around the World; The University of North Texas Press: Denton, TX, USA, 1999.

3. Bosland, P.W. Capsicums: Innovative Uses of An Ancient Crop. In Progress in New Crops; ASHS Press: Arlington, VA, USA, 1996; pp. 479-487.

4. Govindarajan, V.; Salzer, U.J. Capsicum—Production, technology, chemistry, and quality—Part II. Processed products, standards, world production and trade. Crit. Rev. Food Sci. Nutr. 1986, 23, 207-288. [CrossRef] [PubMed]

5. Menichini, F.; Tundis, R.; Bonesi, M.; Loizzo, M.R.; Conforti, F.; Statti, G.; De Cindio, B.; Houghton, P.J.; Menichini, F. The influence of fruit ripening on the phytochemical content and biological activity of Capsicum chinense Jacq. cv Habanero. Food Chem. 2009, 114, 553-560. [CrossRef]

6. Meghvansi, M.; Siddiqui, S.; Khan, M.H.; Gupta, V.; Vairale, M.; Gogoi, H.; Singh, L. Naga chilli: A potential source of capsaicinoids with broad-spectrum ethnopharmacological applications. J. Ethnopharmacol. 2010, 132, 1-14. [CrossRef]

7. Paran, I.; Van Der Knaap, E. Genetic and molecular regulation of fruit and plant domestication traits in tomato and pepper. J. Exp. Bot. 2007, 58, 3841-3852. [CrossRef]

8. Tam, S.M.; Lefebvre, V.; Palloix, A.; Sage-Palloix, A.-M.; Mhiri, C.; Grandbastien, M.-A. LTR-retrotransposons Tnt1 and T135 markers reveal genetic diversity and evolutionary relationships of domesticated peppers. Theor. Appl. Genet. 2009, 119, 973-989. [CrossRef]

9. Saleh, B.K.; Kasili, R.W.; Mamati, E.G.; Yao, K.N.; DeVilliers, S.M.; Araia, W.; Nyende, A.B. Genetic diversity and population structure of Eritrean pepper (Capsicum species) as revealed by SSR markers. Mol. Plant Breed. 2016, 7, 1-16.

10. Batiha, G.E.-S.; Beshbishy, A.M.; El-Mleeh, A.; Abdel-Daim, M.M.; Devkota, H.P. Traditional uses, bioactive chemical constituents, and pharmacological and toxicological activities of Glycyrrhiza glabra L.(Fabaceae). Biomolecules 2020, 10, 352. [CrossRef]

11. Batiha, G.E.-S.; Beshbishy, A.M.; Guswanto, A.; Nugraha, A.; Munkhjargal, T.; Abdel-Daim, M.M.; Mosqueda, J.; Igarashi, I. Phytochemical characterization and chemotherapeutic potential of Cinnamomum verum extracts on the multiplication of protozoan parasites in vitro and in vivo. Molecules 2020, 25, 996. [CrossRef]

12. Andemariam, S.W. Legislative Regulation of Traditional Medicinal Knowledge in Eritrea Via-a-vis Eritrea's Commitments under the Convention on Biological Diversity: Issues and Alternatives. Law Env. Dev. J. 2010, $6,130$.

13. Batiha, G.E.-S.; Beshbishy, A.M.; Wasef, L.G.; Elewa, Y.H.A.; Al-Sagan, A.A.; El-Hack, M.E.A.; Taha, A.E.; Abd-Elhakim, Y.M.M.; Devkota, H.P. Chemical constituents and pharmacological activities of garlic (Allium sativum L.): A review. Nutrients 2020, 12, 872. [CrossRef] [PubMed]

14. Saleh, B.; Omer, A.; Teweldemedhin, B. Medicinal uses and health benefits of chili pepper (Capsicum spp.): A review. MOJ Food Process Technol. 2018, 6, 325-328. [CrossRef]

15. Kirtikar, K.; Basu, B. Indian Medicinal Plants, 2nd ed.; M/S Bishen Singh Pal Singh: Delhi, India, 1975; pp. 1465-1472.

16. Barbero, G.F.; Liazid, A.; Palma, M.; Barroso, C.G. Ultrasound-assisted extraction of capsaicinoids from peppers. Talanta 2008, 75, 1332-1337. [CrossRef] [PubMed] 
17. Kirschbaum-Titze, P.; Hiepler, C.; Mueller-Seitz, E.; Petz, M. Pungency in paprika (Capsicum annuum). 1. Decrease of capsaicinoid content following cellular disruption. J. Agric. Food Chem. 2002, 50, 1260-1263. [CrossRef] [PubMed]

18. Contreras-Padilla, M.; Yahia, E.M. Changes in capsaicinoids during development, maturation, and senescence of chile peppers and relation with peroxidase activity. J. Agric. Food Chem. 1998, 46, 2075-2079. [CrossRef]

19. Santamaria, R.; Reyes-Duarte, M.; Barzana, E.; Fernando, D.; Gama, F.; Mota, M.; Lopez-Munguia, A. Selective enzyme-mediated extraction of capsaicinoids and carotenoids from chili guajillo puya (Capsicum annuum L.) using ethanol as solvent. J. Agric. Food Chem. 2000, 48, 3063-3067. [CrossRef]

20. Williams, O.J.; RAGHAVAN, G.V.; ORSAT, V.; DAI, J. Microwave-assisted extraction of capsaicinoids from capsicum fruit. J. Food Biochem. 2004, 28, 113-122. [CrossRef]

21. Karnka, R.; Rayanakorn, M.; Watanesk, S.; Vaneesorn, Y. Optimization of high-performance liquid chromatographic parameters for the determination of capsaicinoid compounds using the simplex method. Anal. Sci. 2002, 18, 661-665. [CrossRef]

22. Korel, F.G.; Bağdatlioğlu, N.M.; Balaban, M.Ö.; Hişil, Y. Ground red peppers: Capsaicinoids content, Scoville scores, and discrimination by an electronic nose. J. Agric. Food Chem. 2002, 50, 3257-3261. [CrossRef]

23. Daood, H.; Illés, V.; Gnayfeed, M.; Mészáros, B.; Horváth, G.; Biacs, P. Extraction of pungent spice paprika by supercritical carbon dioxide and subcritical propane. J. Supercrit. Fluids 2002, 23, 143-152. [CrossRef]

24. Chen, J.; Wang, F.; Liu, J.; Lee, F.S.-C.; Wang, X.; Yang, H. Analysis of alkaloids in Coptis chinensis Franch by accelerated solvent extraction combined with ultra performance liquid chromatographic analysis with photodiode array and tandem mass spectrometry detections. Anal. Chim. Acta 2008, 613, 184-195. [CrossRef] [PubMed]

25. Dominguez, H.; Nunez, M.; Lema, J. Enzymatic pretreatment to enhance oil extraction from fruits and oilseeds: A review. Food Chem. 1994, 49, 271-286. [CrossRef]

26. Sampathu, S.R.D.; Naidu, M.M.; Sowbhagya, H.B.; Naik, J.P.; Krishnamurthy, N. Process of Extracting Chili (Capsicum) Oleoresin. U.S. Patent 7,097,867, 29 August 2006.

27. Salgado-Roman, M.; Botello-Álvarez, E.; Rico-Martínez, R.; Jiménez-Islas, H.; CÁrdenas-Manríquez, M.; Navarrete-Bolaños, J.L. Enzymatic treatment to improve extraction of capsaicinoids and carotenoids from chili (Capsicum annuum) fruits. J. Agric. Food Chem. 2008, 56, 10012-10018. [CrossRef] [PubMed]

28. Boonkird, S.; Phisalaphong, C.; Phisalaphong, M. Ultrasound-assisted extraction of capsaicinoids from Capsicum frutescens on a lab-and pilot-plant scale. Ultrason. Sonochem. 2008, 15, 1075-1079. [CrossRef] [PubMed]

29. Hetta, H.F.; Mekky, M.A.; Zahran, A.M.; Abdel-Malek, M.O.; Ramadan, H.K.; Shafik, E.A.; Abbas, W.A.; Abbas El-Masry, M.; Mohamed, N.A.; Kamel, A.A.; et al. Regulatory B cells and their cytokine profile in HCV-related hepatocellular carcinoma: Association with regulatory T cells and disease progression. Vaccines. 2020, 8, 380. [CrossRef] [PubMed]

30. Liu, A.; Han, C.; Zhou, X.; Zhu, Z.; Huang, F.; Shen, Y. Determination of three capsaicinoids in C apsicum annuum by pressurized liquid extraction combined with LC-MS/MS. J. Sep. Sci. 2013, 36, 857-862. [CrossRef] [PubMed]

31. Sharif, K.; Rahman, M.; Azmir, J.; Mohamed, A.; Jahurul, M.; Sahena, F.; Zaidul, I. Experimental design of supercritical fluid extraction-A review. J. Food Eng. 2014, 124, 105-116. [CrossRef]

32. Dias, A.L.B.; Sergio, C.S.A.; Santos, P.; Barbero, G.F.; Rezende, C.A.; Martínez, J. Effect of ultrasound on the supercritical CO2 extraction of bioactive compounds from dedo de moça pepper (Capsicum baccatum L. var. pendulum). Ultrason. Sonochem. 2016, 31, 284-294. [CrossRef]

33. De Aguiar, A.C.; Dos Santos, P.; Coutinho, J.P.; Barbero, G.F.; Godoy, H.T.; Martínez, J. Supercritical fluid extraction and low pressure extraction of Biquinho pepper (Capsicum chinense). LWT Food Sci. Technol. 2014, 59, 1239-1246. [CrossRef]

34. Brunner, G. Supercritical fluids: Technology and application to food processing. J. Food Eng. 2005, 67, 21-33. [CrossRef]

35. Santos, P.; Aguiar, A.C.; Barbero, G.F.; Rezende, C.A.; Martínez, J. Supercritical carbon dioxide extraction of capsaicinoids from malagueta pepper (Capsicum frutescens L.) assisted by ultrasound. Ultrason. Sonochem. 2015, 22, 78-88. [CrossRef] [PubMed] 
36. Kantiani, L.; Farré, M.; i Freixiedas, J.M.G.; Barceló, D. Development and validation of a pressurised liquid extraction liquid chromatography-electrospray-tandem mass spectrometry method for $\beta$-lactams and sulfonamides in animal feed. J. Chromatogr. A 2010, 1217, 4247-4254. [CrossRef]

37. Barbero, G.F.; Palma, M.; Barroso, C.G. Pressurized liquid extraction of capsaicinoids from peppers. J. Agric. Food Chem. 2006, 54, 3231-3236. [CrossRef]

38. Barbero, G.F.; Palma, M.; Barroso, C.G. Determination of capsaicinoids in peppers by microwave-assisted extraction-high-performance liquid chromatography with fluorescence detection. Anal. Chim. Acta 2006, 578, 227-233. [CrossRef] [PubMed]

39. Chuichulcherm, S.; Prommakort, S.; Srinophakun, P.; Thanapimmetha, A. Optimization of capsaicin purification from Capsicum frutescens Linn. with column chromatography using Taguchi design. Ind. Crops Prod. 2013, 44, 473-479. [CrossRef]

40. Zaki, N.; Hakmaoui, A.; Ouatmane, A.; Fernandez-Trujillo, J.P. Quality characteristics of Moroccan sweet paprika (Capsicum annuum L.) at different sampling times. Food Sci. Technol. 2013, 33, 577-585. [CrossRef]

41. Durucasu, I.; Tokusoglu, O. Effects of grilling on luteolin (3, 4, 5, 7-tetrahydroxyflavone) content in sweet green bell pepper (capsicum annuum). Pak. J. Biol. Sci. 2007, 10, 3410-3414.

42. Kosuge, S.; Furuta, M. Studies on the pungent principle of Capsicum: Part XIV Chemical Constitution of the Pungent Principle. Agric. Biol. Chem. 1970, 34, 248-256.

43. Toh, C.; Lee, T.; Kiang, A. The pharmacological actions of capsaicin and analogues. Br. J. Pharmacol. Chemother. 1955, 10, 175-182. [CrossRef]

44. Yao, J. An investigation of capsaicinoids and bioactive compounds in'Scotch Bonnet'and seven other cultivars of pepper (Capsicum annuum). Master's Thesis, Michigan State University, East Lansing, MI, USA, 1992; p. 74. [CrossRef]

45. Musfiroh, I.; Mutakin, M.; Angelina, T.; Muchtaridi, M. Capsaicin level of various capsicum fruits. Int. J. Pharm. Pharm. Sci. 2013, 5, 248-251.

46. Kouassi, C.K.; Koffi-Nevry, R.; Guillaume, L.Y.; Yéssé, Z.N.; Koussémon, M.; Kablan, T.; Athanase, K.K. Profiles of bioactive compounds of some pepper fruit (Capsicum L.) varieties grown in Cote d'Ivoire. Innov. Rom. Food Biotechnol. 2012, 11, 23.

47. Medina-Juárez, L.Á.; Molina-Quijada, D.M.; Sánchez, C.L.D.T.; González-Aguilar, G.A.; Gámez-Meza, N. Antioxidant activity of peppers (Capsicum annuum L.) extracts and characterization of their phenolic constituents. Interciencia 2012, 37, 588-593.

48. Gurnani, N.; Gupta, M.; Mehta, D.; Mehta, B.K. Chemical composition, total phenolic and flavonoid contents, and in vitro antimicrobial and antioxidant activities of crude extracts from red chilli seeds (Capsicum frutescens L.). J. Taibah Univ. Sci. 2016, 10, 462-470. [CrossRef]

49. Wesolowska, A.; Jadczak, D.; Grzeszczuk, M. Chemical composition of the pepper fruit extracts of hot cultivars Capsicum annuum L. Acta Sci. Pol. Hortorum Cultus 2011, 10, 171-184.

50. Buczkowska, H.; Michalojc, Z.; Nurzynska-Wierdak, R. Yield and fruit quality of sweet pepper depending on foliar application of calcium. Turk. J. Agric. For. 2016, 40, 222-228. [CrossRef]

51. Marbut, M.M.; Al-Snafi, A.E.; Marbeen, M.I. The probable therapeutic effects of date palm pollen in thetreatment of male infertility. Tikr. J. Pharm. Sci. 2005, 1, 30-35.

52. Al-Snafi, A.E. Bioactive components and pharmacological effects of Canna indica-An Overview. Int. J. Pharmacol. Toxicol. 2015, 5, 71-75.

53. Bano, M.; Sivaramakrishnan, V. Preparation and properties of L-asparaginase from green chillies (Capsicum annum L.). J. Biosci. 1980, 2, 291-297. [CrossRef]

54. Wangcharoen, W.; Morasuk, W. Antioxidant capacity changes of bird chili (Capsicum frutescens Linn) during hot air drying. Kasetsart J. 2009, 43, 12-20.

55. Snitker, S.; Fujishima, Y.; Shen, H.; Ott, S.; Pi-Sunyer, X.; Furuhata, Y.; Sato, H.; Takahashi, M. Effects of novel capsinoid treatment on fatness and energy metabolism in humans: Possible pharmacogenetic implications. Am. J. Clin. Nutr. 2009, 89, 45-50. [CrossRef]

56. Vinayaka, K.; Prashith-Kekuda, T.; Nandini, K.; Rakshitha, M.; Ramya, M.; Shruthi, J.; Nagashree, G.; Anitha, B. Potent insecticidal activity of fruits and leaves of Capsicum frutescens (L.) var. longa (Solanaceae). Der Pharm. Lett. 2010, 2, 172-176.

57. Pershing, L.K.; Reilly, C.A.; Corlett, J.L.; Crouch, D.J. Effects of vehicle on the uptake and elimination kinetics of capsaicinoids in human skin in vivo. Toxicol. Appl. Pharmacol. 2004, 200, 73-81. [CrossRef] [PubMed] 
58. Wahyuni, Y.; Ballester, A.-R.; Tikunov, Y.; De Vos, R.C.; Pelgrom, K.T.; Maharijaya, A.; Sudarmonowati, E.; Bino, R.J.; Bovy, A.G. Metabolomics and molecular marker analysis to explore pepper (Capsicum sp.) biodiversity. Metabolomics 2013, 9, 130-144. [CrossRef]

59. Huang, W.; Cheang, W.S.; Wang, X.; Lei, L.; Liu, Y.; Ma, K.Y.; Zheng, F.; Huang, Y.; Chen, Z.-Y. Capsaicinoids but not their analogue capsinoids lower plasma cholesterol and possess beneficial vascular activity. J. Agric. Food Chem. 2014, 62, 8415-8420. [CrossRef] [PubMed]

60. Suzuki, T.; Iwai, K. Constituents of Red Pepper Species: Chemistry, Biochemistry, Pharmacology, and Food Science of the Pungent principle of Capsicum Species. Alkaloids Chem. Pharmacol 1984, 23, 227-299.

61. Sukrasno, N.; Yeoman, M. Phenylpropanoid metabolism during growth and development of Capsicum frutescens fruits. Phytochemistry 1993, 32, 839-844. [CrossRef]

62. Lee, Y.; Howard, L.; Villalon, B. Flavonoids and antioxidant activity of fresh pepper (Capsicum annuum) cultivars. J. Food Sci. 1995, 60, 473-476. [CrossRef]

63. Loizzo, M.R.; Tundis, R.; Menichini, F.; Statti, G.A.; Menichini, F. Influence of ripening stage on health benefits properties of Capsicum annuum var. acuminatum L.: In vitro studies. J. Med. Food 2008, 11, 184-189. [CrossRef]

64. Davies, B.; Matthews, S.; Kirk, J. The nature and biosynthesis of the carotenoids of different colour varieties of Capsicum annuum. Phytochemistry 1970, 9, 797-805. [CrossRef]

65. Osuna-García, J.A.; Wall, M.M.; Waddell, C.A. Endogenous levels of tocopherols and ascorbic acid during fruit ripening of New Mexican-type chile (Capsicum annuum L.) cultivars. J. Agric. Food Chem. 1998, 46, 5093-5096. [CrossRef]

66. Lee, J.-H.; Kiyota, N.; Ikeda, T.; Nohara, T. Acyclic diterpene glycosides, capsianosides C, D, E, F and III, from the fruits of hot red pepper Capsicum annuum L. used in Kimchi and their revised structures. Chem. Pharm. Bull. 2007, 55, 1151-1156. [CrossRef] [PubMed]

67. Davey, M.W.; Montagu, M.v.; Inze, D.; Sanmartin, M.; Kanellis, A.; Smirnoff, N.; Benzie, I.J.J.; Strain, J.J.; Favell, D.; Fletcher, J. Plant L-ascorbic acid: Chemistry, function, metabolism, bioavailability and effects of processing. J. Sci. Food Agric. 2000, 80, 825-860. [CrossRef]

68. Haynes, R.K.; Vonwiller, S.C. Extraction of artemisinin and artemisinic acid: Preparation of artemether and new analogues. Trans. Royal Soc. Trop. Med. Hyg. 1994, 88, 23-26. [CrossRef]

69. Andrews, J. Peppers: The Domesticated Capsicums; University of Texas Press: Austin, TX, USA, 1995.

70. Fayos, O.; Savirón, M.; Orduna, J.; Mallor, C.; Barbero, G.F.; Garcés-Claver, A. Detection of capsinoids by ESI-mass analysis. Breakthr. Genet. Breed. Capsicum Eggplant 2013, 685.

71. Kobata, K.; Tate, H.; Iwasaki, Y.; Tanaka, Y.; Ohtsu, K.; Yazawa, S.; Watanabe, T. Isolation of coniferyl esters from Capsicum baccatum L., and their enzymatic preparation and agonist activity for TRPV1. Phytochemistry 2008, 69, 1179-1184. [CrossRef]

72. Perucka, I.; Materska, M. Antioxidant vitamin contents of Capsicum annuum fruit extracts as affected by processing and varietal factors. ACTA Sci. Pol. Technol. Aliment. 2007, 6, 67-73.

73. Kawaguchi, Y.; Ochi, T.; Takaishi, Y.; Kawazoe, K.; Lee, K.-H. New sesquiterpenes from Capsicum annuum. J. Nat. Prod. 2004, 67, 1893-1896. [CrossRef]

74. Materska, M.; Perucka, I. Antioxidant activity of the main phenolic compounds isolated from hot pepper fruit (Capsicum annuum L.). J. Agric. Food Chem. 2005, 53, 1750-1756. [CrossRef] [PubMed]

75. Al-Snafi, A.E. Therapeutic properties of medicinal plants: A review of plants with hypolipidemic, hemostatic, fibrinolytic and anticoagulant effects (part 1). Asian J. Pharm. Sci. Technol. 2015, 5, 271-284.

76. Kouassi, C.K.; Koffi-Nevry, R. Evaluation de la connaissance et utilisation des variétés de piment (Capsicum) cultivées en Côte d'Ivoire. Int. J. Biol. Chem. Sci. 2012, 6, 175-185. [CrossRef]

77. Larsen, K.; Jain, S.K.; De Filipps, R.A. Medicinal plants of India. 1-2.-Reference Publ., Inc. Michigan. 849 pp.-Price 95 USD. ISBN 0-917256-39-5. Nord. J. Botany. 1992, 12, 314. [CrossRef]

78. Sumner, J. The Natural History of Medicinal Plants; Timber Press: Portland, OR, USA, 2000.

79. Nip, W.-K. Handbook of Food and Beverage Fermentation Technology; University of Hawaii at Manoa: Honolulu, HI, USA, 2004; Volume 133, p. 60.

80. Sunil, P.; Sanjay, Y.; Vinod, S. Pharmacognostical investigation and standardization of capsicum annum 1. Roots. Chem. Pharm. Bull. 1990, 38, 1299. 
81. Magdy Beshbishy, A.; Alghamdi, S.; Onyiche, T.E.; Zahoor, M.; Rivero-Perez, N.; Zaragoza-Bastida, A.; Ghorab, M.A.; Meshaal, A.K.; El-Esawi, M.A.; Hetta, H.F.; et al. Biogenesis, biologic function and clinical potential of exosomes in different diseases. Applied Sci. 2020, 10, 4428. [CrossRef]

82. Bianchi, R.; Cervellini, I.; Porretta-Serapiglia, C.; Oggioni, N.; Burkey, B.; Ghezzi, P.; Cavaletti, G.; Lauria, G. Beneficial effects of PKF275-055, a novel, selective, orally bioavailable, long-acting dipeptidyl peptidase IV inhibitor in streptozotocin-induced diabetic peripheral neuropathy. J. Pharmacol. Exp. Ther. 2012, 340, 64-72. [CrossRef] [PubMed]

83. Szolcsanyi, J. A pharmacological approach to elucidation of the role of different nerve fibres and receptor endings in mediation of pain. J. De Physiol. 1977, 73, 251-259.

84. Carpenter, S.E.; Lynn, B. Vascular and sensory responses of human skin to mild injury after topical treatment with capsaicin. Br. J. Pharmacol. 1981, 73, 755-758. [CrossRef]

85. Fusco, B.; Giacovazzo, M. Peppers and pain. The promise of capsaicin. Drugs 1997, 53, 909-914. [CrossRef]

86. Simone, D.A.; Nolano, M.; Johnson, T.; Wendelschafer-Crabb, G.; Kennedy, W.R. Intradermal injection of capsaicin in humans produces degeneration and subsequent reinnervation of epidermal nerve fibers: Correlation with sensory function. J. Neurosci. 1998, 18, 8947-8959. [CrossRef]

87. Oh, S.H.; Kim, Y.S.; Lim, S.C.; Hou, Y.F.; Chang, I.Y.; You, H.J. Dihydrocapsaicin (DHC), a saturated structural analog of capsaicin, induces autophagy in human cancer cells in a catalase-regulated manner. Autophagy 2008, 4, 1009-1019. [CrossRef]

88. Careaga, M.; Fernández, E.; Dorantes, L.; Mota, L.; Jaramillo, M.E.; Hernandez-Sanchez, H. Antibacterial activity of Capsicum extract against Salmonella typhimurium and Pseudomonas aeruginosa inoculated in raw beef meat. Int. J. Food Microbiol. 2003, 83, 331-335. [CrossRef]

89. Shayan, S.; Saeidi, S. Antibacterial and antibiofilm activities of extract Capsicum annuum L on the growth and biofilm formation of common pathogenic strains. Int. Res.J. Appl. Basic Sci. 2013, 5, 513-518.

90. De Lucca, A.; Boue, S.; Palmgren, M.; Maskos, K.; Cleveland, T. Fungicidal properties of two saponins from Capsicum frutescens and the relationship of structure and fungicidal activity. Can. J. Microbiol. 2006, 52, 336-342. [CrossRef] [PubMed]

91. Soumya, S.; Nair, B.R. Antifungal efficacy of Capsicum frutescens L. extracts against some prevalent fungal strains associated with groundnut storage. J. Agric. Technol. 2012, 8, 739-750.

92. Dastagir, M.G.; Husaain, M.M.; Billah, A.M.; Ismail, M.; Quader, A. Phytochemical studies on Capsicum frutescens. Int. J. Pharm. Sci. Res. 2012, 3, 1507.

93. Shabnam, A.; Shayesteh, N. Insecticidal Activity of black pepper and red pepper in powdered form on adult of Rhyzopertha dominica (F) and Sitophilus granaries (L.). Pak. Entomol. 2009, 31, 122-127.

94. Diz, M.S.; Carvalho, A.O.; Rodrigues, R.; Neves-Ferreira, A.G.C.; Da Cunha, M.; Alves, E.W.; Okorokova-Façanha, A.L.; Oliveira, M.A.; Perales, J.; Machado, O.L. Antimicrobial peptides from chilli pepper seeds causes yeast plasma membrane permeabilization and inhibits the acidification of the medium by yeast cells. Biochim. Et Biophys. Acta BBA General Subj. 2006, 1760, 1323-1332. [CrossRef]

95. Hafiz, T.; Mubaraki, M.; Dkhil, M.; Al-Quraishy, S. Antiviral activities of Capsicum annuum methanolic extract against herpes simplex virus 1 and 2. Pak. J. Zool. 2017, 49, 251-255. [CrossRef]

96. Oni, M. Evaluation of seed and fruit powders of Capsicum annum and Capsicum frutescens for control of Callosobruchus maculatus (F.) in stored cowpea and Sitophilus zeamais (Motsch) in stored maize. Int. J. Biol. 2011, 3, 185. [CrossRef]

97. Ileke, K.D.; Bulus, D.S.; Aladegoroye, A.Y. Effects of three medicinal plant products on survival, oviposition and progeny development of cowpea bruchid, Callosobruchus maculatus (Fab.)(Coleoptera: Chrysomelidae) infesting cowpea seeds in storage. Jordan J. Biol. Sci. 2013, 147, 1-6. [CrossRef]

98. Ling, F.; Wang, J.-G.; Lu, C.; Wang, G.-X.; Lui, Y.-H.; Gong, X.-N. Effects of aqueous extract of Capsicum frutescens (Solanaceae) against the fish ectoparasite Ichthyophthirius multifiliis. Parasitol. Res. 2012, 111, 841-848. [CrossRef]

99. Ahuja, K.D.; Ball, M.J. Effects of daily ingestion of chilli on serum lipoprotein oxidation in adult men and women. Br. J. Nutr. 2006, 96, 239-242. [CrossRef] [PubMed]

100. Frischkorn, C.; Frischkorn, H.; Carrazzoni, E. Cercaricidal activity of some essential oils of plants from Brazil. Naturwissenschaften 1978, 65, 480-483. [CrossRef] 
101. Hervert-HernÁndez, D.; SÁyago-Ayerdi, S.G.; GONi, I. Bioactive compounds of four hot pepper varieties (Capsicum annuum L.), antioxidant capacity, and intestinal bioaccessibility. J. Agric. Food Chem. 2010, 58, 3399-3406. [CrossRef] [PubMed]

102. Deli, J.; Molnar, P.; Matus, Z.; Toth, G. Carotenoid composition in the fruits of red paprika during ripening: Biosynthesis of carotenoids in red paprika. J. Agr. Food Chem. 2001, 49, 1517-1523. [CrossRef] [PubMed]

103. Rosa, A.; Deiana, M.; Casu, V.; Paccagnini, S.; Appendino, G.; Ballero, M.; Dessí, M.A. Antioxidant activity of capsinoids. J. Agric. Food Chem. 2002, 50, 7396-7401. [CrossRef]

104. Ochi, T.; Takaishi, Y.; Kogure, K.; Yamauti, I. Antioxidant Activity of a New Capsaicin Derivative from Capsicum a nnuum. J. Nat. Prod. 2003, 66, 1094-1096. [CrossRef]

105. Howard, L.; Talcott, S.; Brenes, C.; Villalon, B. Changes in phytochemical and antioxidant activity of selected pepper cultivars (Capsicum species) as influenced by maturity. J. Agric. Food Chem. 2000, 48, 1713-1720. [CrossRef]

106. Marín, A.; Ferreres, F.; Tomás-Barberán, F.A.; Gil, M.I. Characterization and quantitation of antioxidant constituents of sweet pepper (Capsicum annuum L.). J. Agric. Food Chem. 2004, 52, 3861-3869. [CrossRef]

107. Kappel, V.D.; Costa, G.M.; Scola, G.; Silva, F.A.; Landell, M.F.; Valente, P.; Souza, D.G.; Vanz, D.C.; Reginatto, F.H.; Moreira, J.C. Phenolic content and antioxidant and antimicrobial properties of fruits of Capsicum baccatum L. var. pendulum at different maturity stages. J. Med. Food 2008, 11, 267-274. [CrossRef]

108. Popovich, D.G.; Sia, S.Y.; Zhang, W.; Lim, M.L. The color and size of chili peppers (Capsicum annuum) influence Hep-G2 cell growth. Int. J. Food Sci. Nutr. 2014, 65, 881-885. [CrossRef]

109. Hernández-Ortega, M.; Ortiz-Moreno, A.; Hernández-Navarro, M.D.; Chamorro-Cevallos, G.; Dorantes-Alvarez, L.; Necoechea-Mondragón, H. Antioxidant, antinociceptive, and anti-inflammatory effects of carotenoids extracted from dried pepper (Capsicum annuum L.). J. Biomed. Biotechnol. 2012, 2012, 524019. [CrossRef] [PubMed]

110. Srinivasan, K. Spices as influencers of body metabolism: An overview of three decades of research. Food Res. Int. 2005, 38, 77-86. [CrossRef]

111. Aizawa, K.; Inakuma, T. Dietary capsanthin, the main carotenoid in paprika (Capsicum annuum), alters plasma high-density lipoprotein-cholesterol levels and hepatic gene expression in rats. Br. J. Nutr. 2009, 102, 1760-1766. [CrossRef]

112. Libby, P.; Ridker, P.M.; Maseri, A. Inflammation and atherosclerosis. Circulation 2002, 105, 1135-1143. [CrossRef]

113. Arroyo, A.G.; Iruela-Arispe, M.L. Extracellular matrix, inflammation, and the angiogenic response. Cardiovasc. Res. 2010, 86, 226-235. [CrossRef] [PubMed]

114. Rodríguez-Burruezo, A.; González-Mas, M.d.C.; Nuez, F. Carotenoid composition and vitamin A value in ají (Capsicum baccatum L.) and rocoto (C. pubescens R. \& P.), 2 pepper species from the Andean region. J. Food Sci. 2010, 75, S446-S453. [PubMed]

115. Kollmannsberger, H.; Rodríguez-Burruezo, A.; Nitz, S.; Nuez, F. Volatile and capsaicinoid composition of ají (Capsicum baccatum) and rocoto (Capsicum pubescens), two Andean species of chile peppers. J. Sci. Food Agric. 2011, 91, 1598-1611. [CrossRef]

116. Persson, M.; Stocks, J.; Walsh, D.A.; Doherty, M.; Zhang, W. The relative efficacy of topical non-steroidal anti-inflammatory drugs and capsaicin in osteoarthritis: A network meta-analysis of randomised controlled trials. Osteoarthritis Cartilage. 2018, 26, 1575-1582. [CrossRef]

117. Toda, N.; Usui, H.; Nishino, N.; Fujiwara, M. Cardiovascular effects of capsaicin in dogs and rabbits. J. Pharmacol. Exp. Ther. 1972, 181, 512-521.

118. Jolayemi, A.; Ojewole, J. Comparative anti-inflammatory properties of Capsaicin and ethylaAcetate extract of Capsicum frutescens linn [Solanaceae] in rats. Afr. Health Sci. 2013, 13, 357-361. [CrossRef]

119. Baek, J.; Lee, J.; Kim, K.; Kim, T.; Kim, D.; Kim, C.; Tsutomu, K.; Ochir, S.; Lee, K.; Park, C.H. Inhibitory effects of Capsicum annuum L. water extracts on lipoprotein lipase activity in 3T3-L1 cells. Nutr. Res. Pract. 2013, 7, 96-102. [CrossRef] [PubMed]

120. Takano, F.; Yamaguchi, M.; Takada, S.; Shoda, S.; Yahagi, N.; Takahashi, T.; Ohta, T. Capsicum ethanol extracts and capsaicin enhance interleukin-2 and interferon-gamma production in cultured murine Peyer's patch cells ex vivo. Life Sci. 2007, 80, 1553-1563. [CrossRef] [PubMed]

121. Gupta, R.; Dixit, V.; Dobhal, M. Hypocholesterolaemic effect of the oleoresin of Capsicum annum L. in gerbils (Meriones hurrianae Jerdon). Phytother. Res. 2002, 16, 273-275. [CrossRef] [PubMed] 
122. Badia, A.D.; Spina, A.A.; Vassalotti, G. Capsicum annuum L.: An Overview of Biological Activities and Potential Nutraceutical Properties in Humans and Animals. J. Nutr. Ecol. Food Res. 2017, 4, 167-177. [CrossRef]

123. Tag, H.M.; Kelany, O.E.; Tantawy, H.M.; Fahmy, A.A. Potential anti-inflammatory effect of lemon and hot pepper extracts on adjuvant-induced arthritis in mice. J. Basic Appl. Zool. 2014, 67, 149-157. [CrossRef]

124. Sarwa, K.K.; Das, P.J.; Mazumder, B. A nanovesicle topical formulation of Bhut Jolokia (hottest capsicum): A potential anti-arthritic medicine. Expert Opin. Drug Deliv. 2014, 11, 661-676. [CrossRef]

125. Baruah, S.; Zaman, M.K.; Rajbongshi, P.; Das, S. A review on recent researches on Bhut jolokia and pharmacological activity of capsaicin. Int. J. Pharm. Sci. Rev. Res. 2014, 24, 89-94.

126. Liang, Y.T.; Tian, X.-Y.; Chen, J.N.; Peng, C.; Ma, K.Y.; Zuo, Y.; Jiao, R.; Lu, Y.; Huang, Y.; Chen, Z.-Y. Capsaicinoids lower plasma cholesterol and improve endothelial function in hamsters. Eur. J. Nutr. 2013, 52, 379-388. [CrossRef]

127. Srinivasan, K. Biological activities of red pepper (Capsicum annuum) and its pungent principle capsaicin: A review. Crit. Rev. Food Sci. Nutr. 2016, 56, 1488-1500. [CrossRef]

128. Hogaboam, C.M.; Wallace, J.L. Inhibition of platelet aggregation by capsaicin. An effect unrelated to actions on sensory afferent neurons. Eur. J. Pharmacol. 1991, 202, 129-131. [CrossRef]

129. Prashar, D.; Singh, S.; Kumar, S.; Thakur, N.; Kumar, S. Pharmacological and Economical Miracles-Five Common Spices. Asian J. Pharm. Med. Sci. 2012, 2, 2.

130. Omar, O.A.S.; Bukhari, H.M.; ElSawy, N.A.; Header, E.A. Efficacy of capsicum frutescens in curing the peptic ulcer. Int. J. Pure Appl. Sci. Technol. 2013, 15, 43.

131. Haramizu, S.; Kawabata, F.; Ohnuki, K.; Inoue, N.; Watanabe, T.; Yazawa, S.; Fushiki, T. Capsiate, a non-pungent capsaicin analog, reduces body fat without weight rebound like swimming exercise in mice. Biomed. Res. 2011, 32, 279-284. [CrossRef] [PubMed]

132. Yashiro, K.; Tonson, A.; Pecchi, É.; Vilmen, C.; Le Fur, Y.; Bernard, M.; Bendahan, D.; Giannesini, B. Capsiate supplementation reduces oxidative cost of contraction in exercising mouse skeletal muscle in vivo. PLoS ONE 2015, 10, e0128016. [CrossRef] [PubMed]

133. Ono, K.; Tsukamoto-Yasui, M.; Hara-Kimura, Y.; Inoue, N.; Nogusa, Y.; Okabe, Y.; Nagashima, K.; Kato, F. Intragastric administration of capsiate, a transient receptor potential channel agonist, triggers thermogenic sympathetic responses. J. Appl. Physiol. 2011, 110, 789-798. [CrossRef] [PubMed]

134. Ohyama, K.; Nogusa, Y.; Shinoda, K.; Suzuki, K.; Bannai, M.; Kajimura, S. A synergistic antiobesity effect by a combination of capsinoids and cold temperature through promoting beige adipocyte biogenesis. Diabetes 2016, 65, 1410-1423. [CrossRef]

135. Beltran, J.; Ghosh, A.K.; Basu, S. Immunotherapy of tumors with neuroimmune ligand capsaicin. J. Immunol. 2007, 178, 3260-3264. [CrossRef]

136. Potente, M.; Gerhardt, H.; Carmeliet, P. Basic and therapeutic aspects of angiogenesis. Cell 2011, 146, $873-887$. [CrossRef]

137. Folkman, J. Role of angiogenesis in tumor growth and metastasis. Semin. Oncol. 2002, 29, 15-18. [CrossRef]

138. Lin, Z.; Zhang, Q.; Luo, W. Angiogenesis inhibitors as therapeutic agents in cancer: Challenges and future directions. Eur. J. Pharmacol. 2016, 793, 76-81. [CrossRef]

139. Folkman, J. Tumor angiogenesis: Therapeutic implications. N. Engl. J. Med. 1971, 285, 1182-1186. [PubMed]

140. Batiha, G.E.S.; Tayebwa, D.S.; Beshbishy, A.M.; N’Da, D.D.; Yokoyama, N.; Igarashi, I. Inhibitory effects of novel ciprofloxacin derivatives on the growth of four Babesia species and Theileria equi. Parasit. Rese 2020, 1-13. [CrossRef] [PubMed]

141. Ye, W. The complexity of translating anti-angiogenesis therapy from basic science to the clinic. Dev. Cell 2016, 37, 114-125. [CrossRef] [PubMed]

142. Min, J.-K.; Han, K.-Y.; Kim, E.-C.; Kim, Y.-M.; Lee, S.-W.; Kim, O.-H.; Kim, K.-W.; Gho, Y.S.; Kwon, Y.-G. Capsaicin inhibits in vitro and in vivo angiogenesis. Cancer Res. 2004, 64, 644-651. [CrossRef] [PubMed]

143. Pyun, B.-J.; Choi, S.; Lee, Y.; Kim, T.-W.; Min, J.-K.; Kim, Y.; Kim, B.-D.; Kim, J.-H.; Kim, T.-Y.; Kim, Y.-M. Capsiate, a nonpungent capsaicin-like compound, inhibits angiogenesis and vascular permeability via a direct inhibition of Src kinase activity. Cancer Res. 2008, 68, 227-235. [CrossRef]

144. Friedman, J.R.; Nolan, N.A.; Brown, K.C.; Miles, S.L.; Akers, A.T.; Colclough, K.W.; Seidler, J.M.; Rimoldi, J.M.; Valentovic, M.A.; Dasgupta, P. Anticancer activity of natural and synthetic capsaicin analogs. J. Pharmacol. Exp. Ther. 2018, 364, 462-473. [CrossRef] 
145. Holzer, P.; Lippe, I.T. Stimulation of afferent nerve endings by intragastric capsaicin protects against ethanol-induced damage of gastric mucosa. Neuroscience 1988, 27, 981-987. [CrossRef]

146. Clark, R.; Lee, S.-H. Anticancer properties of capsaicin against human cancer. Anticancer Res. 2016, 36, 837-843.

147. Ito, K.; Nakazato, T.; Yamato, K.; Miyakawa, Y.; Yamada, T.; Hozumi, N.; Segawa, K.; Ikeda, Y.; Kizaki, M. Induction of apoptosis in leukemic cells by homovanillic acid derivative, capsaicin, through oxidative stress: Implication of phosphorylation of p53 at Ser-15 residue by reactive oxygen species. Cancer Res. 2004, 64, 1071-1078. [CrossRef]

148. Basith, S.; Cui, M.; Hong, S.; Choi, S. Harnessing the therapeutic potential of capsaicin and its analogues in pain and other diseases. Molecules 2016, 21, 966. [CrossRef]

149. Maoka, T.; Mochida, K.; Kozuka, M.; Ito, Y.; Fujiwara, Y.; Hashimoto, K.; Enjo, F.; Ogata, M.; Nobukuni, Y.; Tokuda, H. Cancer chemopreventive activity of carotenoids in the fruits of red paprika Capsicum annuum L. Cancer Lett. 2001, 172, 103-109. [CrossRef]

150. Lo, Y.-C.; Yang, Y.-C.; Wu, I.-C.; Kuo, F.-C.; Liu, C.-M.; Wang, H.-W.; Kuo, C.-H.; Wu, J.-Y.; Wu, D.-C. Capsaicin-induced cell death in a human gastric adenocarcinoma cell line. World J. Gastroenterol. WJG 2005, 11, 6254. [CrossRef] [PubMed]

151. Macho, A.; Lucena, C.; Sancho, R.; Daddario, N.; Minassi, A.; Muñoz, E.; Appendino, G. Non-pungent capsaicinoids from sweet pepper. Eur. J. Nutr. 2003, 42, 2-9. [CrossRef] [PubMed]

152. Nassar, A.M.; Salim, Y.M.; Eid, K.S.; Shaheen, H.M.; Saati, A.A.; Hetta, H.F.; Elmistekawy, A.; Batiha, G.E.S. Ameliorative effects of honey, propolis, pollen, and royal jelly mixture against chronic toxicity of Sumithion insecticide in white albino rats. Molecules. 2020, 25, 2633. [CrossRef]

153. Sánchez-Sánchez, L.; Alvarado-Sansininea, J.J.; Escobar, M.L.; López-Muñoz, H.; Hernández-Vázquez, J.M.; Monsalvo-Montiel, I.; Demare, P.; Regla, I.; Weiss-Steider, B. Evaluation of the antitumour activity of Rinvanil and Phenylacetylrinvanil on the cervical cancer tumour cell lines HeLa, CaSKi and ViBo. Eur. J. Pharmacol. 2015, 758, 129-136. [CrossRef]

154. Tuoya, B.N.; Shimoishi, Y.; Murata, Y.; Tada, M.; Koseki, M.; Takahata, K. Apoptosis induction by dohevanil, a DHA substitutive analog of capsaicin. MCF 7 Cells Life Sci. 2006, 78, 1515-1519.

155. Appendino, G.; De Petrocellis, L.; Trevisani, M.; Minassi, A.; Daddario, N.; Moriello, A.S.; Gazzieri, D.; Ligresti, A.; Campi, B.; Fontana, G. Development of the first ultra-potent "capsaicinoid" agonist at transient receptor potential vanilloid type 1 (TRPV1) channels and its therapeutic potential. J. Pharmacol. Exp. Ther. 2005, 312, 561-570. [CrossRef]

156. Petruzzelli, G.J. The biology of tumor invasion, angiogenesis and lymph node metastasis. ORL 2000, 62, 178-185. [CrossRef]

157. Yang, J.; Li, T.; Xu, G.; Luo, B.; Chen, Y.; Zhang, T. Low-concentration capsaicin promotes colorectal cancer metastasis by triggering ROS production and modulating Akt/mTOR and STAT-3 pathways. Neoplasma 2013, 60, 364-372. [CrossRef]

158. Xu, S.; Zhang, L.; Cheng, X.; Yu, H.; Bao, J.; Lu, R. Capsaicin inhibits the metastasis of human papillary thyroid carcinoma BCPAP cells through the modulation of the TRPV1 channel. Food Funct. 2018, 9, 344-354. [CrossRef]

159. Hurley, J.D.; Akers, A.T.; Friedman, J.R.; Nolan, N.A.; Brown, K.C.; Dasgupta, P. Non-pungent long chain capsaicin-analogs arvanil and olvanil display better anti-invasive activity than capsaicin in human small cell lung cancers. Cell Adhes. Migr. 2017, 11, 80-97. [CrossRef] [PubMed]

160. Caprodossi, S.; Amantini, C.; Nabissi, M.; Morelli, M.B.; Farfariello, V.; Santoni, M.; Gismondi, A.; Santoni, G. Capsaicin promotes a more aggressive gene expression phenotype and invasiveness in null-TRPV1 urothelial cancer cells. Carcinogenesis 2011, 32, 686-694. [CrossRef] [PubMed]

161. Wutka, A.; Palagani, V.; Barat, S.; Chen, X.; El Khatib, M.; Götze, J.; Belahmer, H.; Zender, S.; Bozko, P.; Malek, N.P. Capsaicin treatment attenuates cholangiocarcinoma carcinogenesis. PLoS ONE 2014, 9, e95605. [CrossRef] [PubMed]

162. Lin, M.-H.; Lee, Y.-H.; Cheng, H.-L.; Chen, H.-Y.; Jhuang, F.-H.; Chueh, P.J. Capsaicin inhibits multiple bladder cancer cell phenotypes by inhibiting tumor-associated NADH oxidase (tNOX) and sirtuin1 (SIRT1). Molecules 2016, 21, 849. [CrossRef] 
163. Lee, J.H.; Kim, C.; Baek, S.H.; Ko, J.-H.; Lee, S.G.; Yang, W.M.; Um, J.-Y.; Sethi, G.; Ahn, K.S. Capsazepine inhibits JAK/STAT3 signaling, tumor growth, and cell survival in prostate cancer. Oncotarget 2017, 8, 17700. [CrossRef]

164. Frias, B.; Merighi, A. Capsaicin, nociception and pain. Molecules 2016, 21, 797. [CrossRef]

165. O'Neill, J.; Brock, C.; Olesen, A.E.; Andresen, T.; Nilsson, M.; Dickenson, A.H. Unravelling the mystery of capsaicin: A tool to understand and treat pain. Pharmacol. Rev. 2012, 64, 939-971. [CrossRef]

166. Erin, N.; Boyer, P.J.; Bonneau, R.H.; Clawson, G.A.; Welch, D.R. Capsaicin-mediated denervation of sensory neurons promotes mammary tumor metastasis to lung and heart. Anticancer Res. 2004, 24, 1003-1010.

167. Venier, N.A.; Yamamoto, T.; Sugar, L.M.; Adomat, H.; Fleshner, N.E.; Klotz, L.H.; Venkateswaran, V. Capsaicin reduces the metastatic burden in the transgenic adenocarcinoma of the mouse prostate model. Prostate 2015, 75, 1300-1311. [CrossRef]

168. Menéndez, L.; Lastra, A.; Hidalgo, A.n.; Baamonde, A. The analgesic effect induced by capsaicin is enhanced in inflammatory states. Life Sci. 2004, 74, 3235-3244. [CrossRef]

169. Deal, C.L.; Schnitzer, T.J.; Lipstein, E.; Seibold, J.R.; Stevens, R.M.; Levy, M.D.; Albert, D.; Renold, F. Treatment of arthritis with topical capsaicin: A double-blind trial. Clin. Ther. 1991, 13, 383-395. [PubMed]

170. Marks, D.R.; Rapoport, A.; Padla, D.; Weeks, R.; Rosum, R.; Sheftell, F.; Arrowsmith, F. A double-blind placebo-controlled trial of intranasal capsaicin for cluster headache. Cephalalgia 1993, 13, 114-116. [CrossRef] [PubMed]

171. Hayman, M.; Kam, P.C. Capsaicin: A review of its pharmacology and clinical applications. Current Anaesth. Crit. Care 2008, 19, 338-343. [CrossRef]

172. Wang, J.-P.; Hsu, M.-F.; Teng, C.-M. Antiplatelet effect of capsaicin. Thromb. Res. 1984, 36, 497-507. [CrossRef]

173. Roghani, M.; Baluchnejadmojarad, T.; Sohrabi, Z.; Sadeghi, M. Anti-hyperlycemic and hypolipidemic effect of oral administration of Capsicum frutescens in male STZ-diabetic rats. J. Med. Plants 2004, 2, 47-52.

174. Sanati, S.; Razavi, B.M.; Hosseinzadeh, H. A review of the effects of Capsicum annuum L. and its constituent, capsaicin, in metabolic syndrome. Iran. J. Basic Med. Sci. 2018, 21, 439. [PubMed]

175. Parvez, G.M. Current advances in pharmacological activity and toxic effects of various capsicum species. Int. J. Pharm. Sci. Res. 2017, 8, 1900-1912.

176. Ahuja, K.D.; Robertson, I.K.; Geraghty, D.P.; Ball, M.J. Effects of chili consumption on postprandial glucose, insulin, and energy metabolism. Am. J. Clin. Nutr. 2006, 84, 63-69. [CrossRef]

177. Mózsik, G. Capsaicin as New Orally Applicable Gastroprotective and Therapeutic Drug Alone or in Combination with Nonsteroidal Anti-Inflammatory Drugs in Healthy Human Subjects and in Patients. Prog Drug Res. 2014, 68, 209-258. [CrossRef] [PubMed]

178. Maramag, R.P. Diuretic Potential of Capsicum Frutescens Linn., Corchorus Oliturius Linn., and Abelmoschus Esculentus Linn. Asian J. Nat. Appl. Sci. 2013, 2, 60-69.

179. Uchida, M.; Yano, S.; Watanabe, K. The role of capsaicin-sensitive afferent nerves in protective effect of capsaicin against absolute ethanol-induced gastric lesions in rats. Jpn. J. Pharmacol. 1991, 55, 279-282. [CrossRef] [PubMed]

180. Millqvist, E. Cough provocation with capsaicin is an objective way to test sensory hyperreactivity in patients with asthma-like symptoms. Allergy 2000, 55, 546-550. [CrossRef] [PubMed]

181. Stjarne, P.; Rinder, J.; Heden-Blomquist, E.; Cardell, L.O.; Lundberg, J.; Zetterstrom, O.; Ängga, A. Capsaicin desensitization of the nasal mucosa reduces symptoms upon allergen challenge in patients with allergic rhinitis. Acta Oto Laryngol. 1998, 118, 235-239.

182. Dicpinigaitis, P.V.; Alva, R.V. Safety of capsaicin cough challenge testing. Chest 2005, 128, 196-202. [CrossRef] [PubMed]

183. Bernstein, J.E.; Parish, L.C.; Rapaport, M.; Rosenbaum, M.M.; Roenigk Jr, H.H. Effects of topically applied capsaicin on moderate and severe psoriasis vulgaris. J. Am. Acad. Dermatol. 1986, 15, 504-507. [CrossRef]

184. Yosipovitch, G.; Mengesha, Y.; Facliaru, D.; David, M. Topical capsaicin for the treatment of acute lipodermatosclerosis and lobular panniculitis. J. Dermatol. Treat. 2005, 16, 178-180. [CrossRef]

185. Krogstad, A.; Lönnroth, P.; Larson, G.; Wallin, B. Capsaicin treatment induces histamine release and perfusion changes in psoriatic skin. Br. J. Dermatol. 1999, 141, 87-93. [CrossRef] 
186. Neess, C.; Hinrichs, R.; Dissemond, J.; Herrmann, G.; Poswig, A.; Servera-Llanras, M.; Hunzelmann, N.; Brenneisen, P.; Meewes, C.; Krieg, T. Treatment of pruritus by capsaicin in a patient with pityriasis rubra pilaris receiving RE-PUVA therapy: Clinical dermatology Concise report. Clin. Exp. Dermatol. 2000, 25, 209-211. [CrossRef]

187. Lysy, J.; Sistiery-Ittah, M.; Israelit, Y.; Shmueli, A.; Strauss-Liviatan, N.; Mindrul, V.; Keret, D.; Goldin, E. Topical capsaicin-A novel and effective treatment for idiopathic intractable pruritus ani: A randomised, placebo controlled, crossover study. Gut 2003, 52, 1323-1326. [CrossRef]

188. Ellis, C.N.; Berberian, B.; Sulica, V.I.; Dodd, W.A.; Jarratt, M.T.; Katz, H.I.; Prawer, S.; Krueger, G.; Rex Jr, I.H.; Wolf, J.E. A double-blind evaluation of topical capsaicin in pruritic psoriasis. J. Am. Acad. Dermatol. 1993, 29, 438-442. [CrossRef]

189. Ikram, M.; Magdy Beshbishy, A.; Kifayatullah, M.; Olukanni, A.; Zahoor, M.; Naeem, M.; Amin, M.; Shah, M.; Abdelaziz, A.S.; Ullah, R.; et al. Chemotherapeutic potential of Carthamus oxycantha root extract as antidiarrheal and in vitro antibacterial activities. Antibiotics 2020, 9, 226. [CrossRef] [PubMed]

190. Ständer, S.; Luger, T.; Metze, D. Treatment of prurigo nodularis with topical capsaicin. J. Am. Acad. Dermatol. 2001, 44, 471-478. [CrossRef] [PubMed]

191. Reuter, J.; Merfort, I.; Schempp, C.M. Botanicals in dermatology. Am. J. Clin. Dermatol. 2010, 11, $247-267$. [CrossRef] [PubMed]

192. Bourne, N.; Bernstein, D.; Stanberry, L. Civamide (cis-capsaicin) for treatment of primary or recurrent experimental genital herpes. Antimicrob. Agents Chemother. 1999, 43, 2685-2688. [CrossRef]

193. Kwon, Y.I.; Apostolidis, E.; Shetty, K. Evaluation of pepper (Capsicum annuum) for management of diabetes and hypertension. J. Food Biochem. 2007, 31, 370-385. [CrossRef]

194. Kwon, M.-J.; Song, Y.-S.; Choi, M.-S.; Song, Y.-O. Red pepper attenuates cholesteryl ester transfer protein activity and atherosclerosis in cholesterol-fed rabbits. Clin. Chim. Acta 2003, 332, 37-44. [CrossRef]

195. Kim, K.S.; Kim, K.N.; Hwang, K.G.; Park, C.J. Capsicum plaster at the Hegu point reduces postoperative analgesic requirement after orthognathic surgery. Anesth. Analg. 2009, 108, 992-996. [CrossRef]

196. Simpson, D.M.; Brown, S.; Tobias, J. Controlled trial of high-concentration capsaicin patch for treatment of painful HIV neuropathy. Neurology 2008, 70, 2305-2313. [CrossRef]

197. Steinberg, A.C.; Oyama, I.A.; Rejba, A.E.; Kellogg-Spadt, S.; Whitmore, K.E. Capsaicin for the treatment of vulvar vestibulitis. Am. J. Obstet. Gynecol. 2005, 192, 1549-1553. [CrossRef]

198. Johnson, W., Jr. Final Report on the Safety Assessment of Capsicum Annuum Extract, Capsicum Annuum Fruit Extract, Capsicum Annuum Resin, Capsicum Annuum Fruit Powder, Capsicum Frutescens Fruit, Capsicum Frutescens Fruit Extract, Capsicum Frutescens Resin, and Capsaicin. Int. J. Toxicol. 2007, 26, 3-106.

199. Hwang, M.K.; Bode, A.M.; Byun, S.; Song, N.R.; Lee, H.J.; Lee, K.W.; Dong, Z. Cocarcinogenic effect of capsaicin involves activation of EGFR signaling but not TRPV1. Cancer Res. 2010, 70, 6859-6869. [CrossRef] [PubMed]

200. Asai, T.; Tsuchiya, Y.; Okano, K.; Piscoya, A.; Nishi, C.Y.; Ikoma, T.; Oyama, T.; Ikegami, K.; Yamamoto, M. Aflatoxin contamination of red chili pepper from Bolivia and Peru, countries with high gallbladder cancer incidence rates. Asian Pac. J. Cancer Prev. APJCP 2012, 13, 5167-5170. [CrossRef] [PubMed]

201. Tsuchiya, Y.; Terao, M.; Okano, K.; Nakamura, K.; Oyama, M.; Ikegami, K.; Yamamoto, M. Mutagenicity and mutagens of the red chili pepper as gallbladder cancer risk factor in Chilean women. Asian Pac. J. Cancer Prev. APJCP 2011, 12, 471-476. [PubMed]

202. Szallasi, A.; Blumberg, P.M. Vanilloid (Capsaicin) receptors and mechanisms. Pharmacol. Rev. 1999, 51, 159-212.

203. Fleming, T. PDR for Herbal Medicines: From Medical Economics Company; Thomson Reuters: Ann Arbor, MI, USA, 2000; p. 253.

204. Ling, K.H.; Hoon, T.C.; Kian, C.T. A Guide To Medicinal Plants. In An Illustrated Scientific And Medicinal Approach; World Scientific: Singapore, 2009.

205. Saito, A.; Yamamoto, M. Acute oral toxicity of capsaicin in mice and rats. J. Toxicol. Sci. 1996, 21, 195-200. [CrossRef]

206. Reilly, C.A.; Taylor, J.L.; Lanza, D.L.; Carr, B.A.; Crouch, D.J.; Yost, G.S. Capsaicinoids cause inflammation and epithelial cell death through activation of vanilloid receptors. Toxicol. Sci. 2003, 73, 170-181. [CrossRef] 
207. Lininger, S.W. AZ Guide to Drug-Herb-Vitamin Interactions: How to Improve Your Health and Avoid Problems When Using Common Medications and Natural Supplements Together; Three Rivers Press: New York, NY, USA, 1999.

208. Kearney, T.; Hiatt, P.; Birdsall, E.; Smollin, C. Pepper spray injury severity: Ten-year case experience of a poison control system. Prehospital Emerg. Care 2014, 18, 381-386. [CrossRef]

209. Gerber, S.; Frueh, B.E.; Tappeiner, C. Conjunctival proliferation after a mild pepper spray injury in a young child. Cornea 2011, 30, 1042-1044. [CrossRef]

210. Rasier, R.; Kukner, A.S.; Sengul, E.A.; Yalcin, N.G.; Temizsoylu, O.; Bahcecioglu, H.O. The decrease in aqueous tear production associated with pepper spray. Curr. Eye Res. 2015, 40, 429-433. [CrossRef]

211. Batiha, G.E.S.; Olatunde, A.; El-Mleeh, A.; Hetta, H.F.; Al-Rejaie, S.; Alghamdi, S.; Zahoor, M.; Magdy Beshbishy, A.; Murata, T.; Zaragoza-Bastida, A.; et al. Bioactive compounds, pharmacological actions, and pharmacokinetics of wormwood (Artemisia absinthium). Antibiotics 2020, 9, 353. [CrossRef]

212. Geppetti, P.; Fusco, B.M.; Marabini, S.; Maggi, C.A.; Fanciullacci, M.; Sicuteri, F. Secretion, pain and sneezing induced by the application of capsaicin to the nasal mucosa in man. Br. J. Pharmacol. 1988, 93, 509-514. [CrossRef] [PubMed]

213. Smith, C.G.; Stopford, W. Health hazards of pepper spray. N. C. Med. J. 1999, 60, 268-274. [PubMed]

214. Gallo, R.; Cozzani, E.; Guarrera, M. Sensitization to pepper (Capsicum annuum) in a latex-allergic patient. Contact Dermat. 1997, 37, 36-37. [CrossRef] [PubMed]

215. Ebner, C.; Jensen-Jarolim, E.; Leitner, A.; Breiteneder, H. Characterization of allergens in plant-derived spices: Apiaceae spices, pepper (Piperaceae), and paprika (bell peppers, Solanaceae). Allergy 1998, 53, 52-54. [CrossRef]

216. Schep, L.J.; Slaughter, R.J.; McBride, D.I. Riot control agents: The tear gases CN, CS and OC-A medical review. J. R. Army Med. Corps 2015, 161, 94-99. [CrossRef]

217. Chaiyata, P.; Puttadechakum, S.; Komindr, S. Effect of chili pepper (Capsicum frutescens) ingestion on plasma glucose response and metabolic rate in thai. J. Med. Assoc. Thai 2003, 86, 854-860. [PubMed]

218. Weerapan Khovidhunkit, M. Pharmacokinetic and the effect of capsaicin in Capsicum frutescens on decreasing plasma glucose level. J. Med. Assoc. Thai 2009, 92, 108-113.

219. Saria, A.; Skofitsch, G.; Lembeck, F. Distribution of capsaicin in rat tissues after systemic administration. J. Pharm. Pharmacol. 1982, 34, 273-275. [CrossRef]

220. Reilly, C.A.; Ehlhardt, W.J.; Jackson, D.A.; Kulanthaivel, P.; Mutlib, A.E.; Espina, R.J.; Moody, D.E.; Crouch, D.J.; Yost, G.S. Metabolism of capsaicin by cytochrome $\mathrm{P} 450$ produces novel dehydrogenated metabolites and decreases cytotoxicity to lung and liver cells. Chem. Res. Toxicol. 2003, 16, 336-349. [CrossRef]

221. Chanda, S.; Bashir, M.; Babbar, S.; Koganti, A.; Bley, K. In vitro hepatic and skin metabolism of capsaicin. Drug Metab. Dispos. Biol. Fate Chem. 2008, 36, 670-675. [CrossRef]

222. Suresh, D.; Srinivasan, K. Tissue distribution \& elimination of capsaicin, piperine \& curcumin following oral intake in rats. Indian J. Med. Res. 2010, 131, 682-691. [PubMed]

223. Mózsik, G.; Past, T.; Salam, O.M.A.; Kuzma, M.; Perjési, P. Interdisciplinary review for correlation between the plant origin capsaicinoids, non-steroidal antiinflammatory drugs, gastrointestinal mucosal damage and prevention in animals and human beings. Inflammopharmacology 2009, 17, 113-150. [CrossRef]

224. Kawada, T.; Suzuki, T.; Takahashi, M.; Iwai, K. Gastrointestinal absorption and metabolism of capsaicin and dihydrocapsaicin in rats. Toxicol. Appl. Pharmacol. 1984, 72, 449-456. [CrossRef]

225. Reyes-Escogido, M.; Gonzalez-Mondragon, E.G.; Vazquez-Tzompantzi, E. Chemical and pharmacological aspects of capsaicin. Molecules 2011, 16, 1253-1270. [CrossRef]

226. Cortright, D.N.; Szallasi, A. Biochemical pharmacology of the vanilloid receptor TRPV1. Eur. J. Biochem. 2004, 271, 1814-1819. [CrossRef] [PubMed]

227. Chen, X.; Sun, X.; Ren, K.; Zhang, X.; Zhang, Z.; Gong, T. Enhanced aqueous solubility and bioavailability of capsaicin by the preparation of an inclusion complex. Arzneimittelforschung 2010,60, 571-574. [CrossRef] [PubMed]

228. Beshbishy, A.M.; Batiha, G.E.-S.; Yokoyama, N.; Igarashi, I. Ellagic acid microspheres restrict the growth of Babesia and Theileria in vitro and Babesia microti in vivo. Parasit. Vectors 2019, 12, 269. [CrossRef] 
229. Tan, S.; Gao, B.; Tao, Y.; Guo, J.; Su, Z.-q. Antiobese effects of capsaicin-chitosan microsphere (CCMS) in obese rats induced by high fat diet. J. Agric. Food Chem. 2014, 62, 1866-1874. [CrossRef]

230. Rollyson, W.D.; Stover, C.A.; Brown, K.C.; Perry, H.E.; Stevenson, C.D.; McNees, C.A.; Ball, J.G.; Valentovic, M.A.; Dasgupta, P. Bioavailability of capsaicin and its implications for drug delivery. J. Controll. Release 2014, 196, 96-105. [CrossRef] 